Article

\title{
Future Projection of Precipitation Changes in the Júcar and Segura River Basins (Iberian Peninsula) by CMIP5 GCMs Local Downscaling
}

\author{
Juan Javier Miró ${ }^{1}\left(\mathbb{D}\right.$, María José Estrela ${ }^{1, *}$, Jorge Olcina-Cantos ${ }^{2}\left(\mathbb{D}\right.$ and Javier Martin-Vide ${ }^{3}(\mathbb{D})$ \\ 1 Departament de Geografia, Facultat de Geografia i Història, Universitat de València, Avda. Blasco Ibáñez 28, \\ 46010 Valencia, Spain; jamipe@uv.es \\ 2 Laboratorio de Climatología, Instituto Interuniversitario de Geografía, Universidad de Alicante, \\ Ctra. San Vicente del Raspeig s/n, San Vicente del Raspeig, 03690 Alicante, Spain; jorge.olcina@ua.es \\ 3 Laboratori de Climatologia, Departament de Geografia, Facultat de Geografia i Història, \\ Universitat de Barcelona, C/Montalegre, 6, 08001 Barcelona, Spain; jmartinvide@ub.edu \\ * Correspondence: majoesna@uv.es
}

check for

updates

Citation: Miró, J.J.; Estrela, M.J.; Olcina-Cantos, J.; Martin-Vide, J. Future Projection of Precipitation Changes in the Júcar and Segura River Basins (Iberian Peninsula) by CMIP5 GCMs Local Downscaling. Atmosphere 2021, 12, 879. https:// doi.org/10.3390/atmos12070879

Academic Editor: Mario

Marcello Miglietta

Received: 7 June 2021

Accepted: 2 July 2021

Published: 7 July 2021

Publisher's Note: MDPI stays neutral with regard to jurisdictional claims in published maps and institutional affiliations.

Copyright: (c) 2021 by the authors. Licensee MDPI, Basel, Switzerland. This article is an open access article distributed under the terms and conditions of the Creative Commons Attribution (CC BY) license (https:/ / creativecommons.org/licenses/by/ $4.0 /)$.

\begin{abstract}
The basins of the Júcar and Segura rivers, on the Mediterranean coast of the Iberian Peninsula, present a special water problem and are of particular interest regarding climate change. These basins are very vulnerable to a possible scenario of decreasing water resources. Recent studies on historic rainfall since 1955 have indicated an ongoing loss of precipitation in their headwaters, especially in the case of the Júcar river. The aim of the present study is to perform climate projections for the precipitation variable for several future periods (2021-2040, 2051-2070, 2081-2100) and emission scenarios (RCPs 4.5, 8.5) within the Júcar and Segura River Basin authorities. For this purpose, a set of CMIP5 global models have been used, as well as the CDRD-HR-EIP-1955-2016 database, as a source of local observed information. This database comprises nearly 900 precipitation series in both basins and has been used in recent studies to determine historic trends of change in these basins. A statistical downscaling of the global models for all available observed series has been applied using the LARS-WG method. The results, although variable according to the CMIP5 model used, show the continuation of the patterns of precipitation change in the future, as already observed in the historical series. The results also predict a clear reduction in precipitation in the long term. However, torrential rainfall tends to increase in the coastal areas in relation to that observed in the short-term predictions. These results, due to their high spatial resolution, are of great interest for their use in small-scale hydrological and spatial planning (regional and local), which is one of the current challenges of climate modeling.
\end{abstract}

Keywords: climate change; scenarios; downscaling; torrential rains; hydrological planning; CMIP5 GCMs; East of Iberian Peninsula

\section{Introduction}

Climate change is a huge threat in the twenty-first century that poses serious risks for not only the natural environment but also the economy and human life itself [1]. Many studies predict climate changes worldwide with increased climate variability, which implies an increase in extreme heatwaves, severe and persistent droughts, and intense frequent torrential rain that will cause severe floods. This will be most dramatic in those sectors considered to be the hot points of global warming, such as the Mediterranean Basin [2,3]. Floods caused by intense or abundant rainfall are still a natural hazard with a huge annual impact that particularly affects coastal Mediterranean countries [4,5]. Indeed, the hydrological cycle in the Mediterranean Basin will be deeply affected by climate change. Different studies predict that less rain will fall throughout the Mediterranean Region because of not only the increased divergence of water vapor in subtropical areas that will 
move towards the poles [6] but also due to circumpolar vortex contraction [7,8]. In the future, the Mediterranean region will be under subtropical-tropical anticyclonic subsidence for most of the year so there will be a clear reduction in precipitation $[9,10]$. Apart from all this, flood and drought intensity is expected to increase $[7,8]$ and dry periods will prolong [11].

The Júcar and Segura River Basins on the Mediterranean coastline in the Iberian Peninsula are particularly sensitive to climate change because they are extremely vulnerable to a possible scenario with fewer water resources. Recent studies about rainfall records since 1955 indicate that precipitation in their headwaters has constantly been decreasing, especially for the Júcar River. Particularly those studies published since 2000, which include more recent data and more spatial data, have detected structural changes in precipitation as a trend towards higher daily concentrations and greater irregularity [12,13], changes in their monthly and seasonal distribution [14-19] and dry periods lasting longer [20]. Therefore, it can be stated that change trends are underway [18] and are due to changes in both the frequency of atmospheric circulation patterns [16] and the synoptic mechanisms that generate precipitation in these basins [21-23]. These changes are solved with the presence of negative trends noted within the Júcar River Basin Authority (JHC) caused by loss of precipitation linked with Atlantic fronts [22,23]. These trends do not affect the littoral precipitations of both the studied basins (JHC and SHC; Júcar and Segura) because rain is linked with a Mediterranean genesis [22,23].

Future climate conditions of these Mediterranean fluvial basins, marked by great irregularity and a fall in precipitations, will have huge effects on the economy of these regions. Putting into practice actions and measures to cushion their impact on both the population and the tourist/farming sector is fundamental because these sectors are the basic pillars of their economic system. However, maintaining these activities entails a high water demand, which might be compromised in the near future. Given this context, it is necessary to better know how climate change will affect water resources in the short, mid and long terms. The objective of the present study is to make climate projections from the variable precipitation for several periods in the future (2021-2040, 2051-2070, 2081-2100) and under emission scenarios (RCPs $4.5,8.5$ ) in the JHC and SHC.

Given the local spatial resolution of the results, their use in small-scale (municipal and local) hydrological planning is very interesting as this is one of the challenges faced today in climate modeling [24]. Indeed, spatial planning requires high spatial resolution climate models that can be included in proposals about assigning new land uses and urban designs. To date, high-resolution climate models have been used to basically study natural extreme events, especially floods. Kharnel and Kirilenko [25] employ high-resolution spatial modeling to estimate streamflow height and to devise adaptation strategies in the Devils Lake region (North Dakota, USA). Navarro-Racines et al. [26] point out the suitability of these high-resolution models for agrarian planning and studying biodiversity, who obtained very interesting results for South America. On the local scale, town planning actions are performed that include high-resolution climate modeling when designing proposals to adapt to climate change. Work is generally done on temperature evolution (heat islands) and precipitation intensity. Zhao et al. [27] work on multi model highresolution climate projections to analyze climate evolution in cities in different regions and countries around the world (USA, Middle East, North Central Asia, NE China, and inland areas of South America and Africa) that will undergo considerable warming of more than $4{ }^{\circ} \mathrm{K}$, above regional warming, by the end of the century for RCP 8.5 , with high reliability among models. Their study stresses the need for high-resolution local-scale modeling for sustainable town planning with a green infrastructure in an efficient environment to reduce urban heat stress. In the German city of Jena, the climate projections for the period from 2051 to 2100 indicate not only an increase of $3{ }^{\circ} \mathrm{C}$ (CMIP5, RCP 4.5) to $6{ }^{\circ} \mathrm{C}$ (CMIP5, RCP 8.5) for the average maximum temperature in summer by the end of the century but also an increase in the average number of hot days ( $\operatorname{Tmax} \geq 30^{\circ} \mathrm{C}$ ) from 11 to 35 (CMIP5, RCP 4.5) and to 49 (CMIP5, RCP 8.5) [28]. Mishra et al. [29] work with HadGEM2-ES models to 
analyze changes in precipitations and floods for mid-term scenarios (50 years) with Yakarta floods to manage urban drainage infrastructures and to develop adaptation measures. Hassan et al. [30] deal with CMIP5 modeling (RCP 4.5 and 8.5) to study the evolution of precipitation and temperature in the Niger Delta (Nigeria) to design hydrological planning and territorial adaptation measures.

As an alternative to the RCMs and the downscaling methods, the Stochastics Rainfall Generators allow investigating the effects of climate change at the finest hydrological scales [31-33]. In the Stochastics Rainfall Generators the parameters are perturbed when considering the changes predicted by the RCMs, under the hypothesis that the statistics of actually averaged precipitation simulated by climate models reflects changes in the scale of the point rain gauge [34,35].

Analyses that establish future climate change scenarios are based on global models. One of the most recent ones is CMIP5-despite CMIP6 being in progress-which has acted as the basis to update National Climate Change Adaptation Plan [36] scenarios in Spain. To fulfill the objective of this work, several CMIP5 global models have been used, particularly those with the finest resolution as mesoscale processes are determining factors in the Mediterranean climate, which must be modeled in high spatial resolution to obtain very reliable results. Reducing the release of GCMs at very fine resolutions is very useful on a local scale, particularly when analyzing potential changes in available water resources to evaluate their impact on the highly dependent natural environment, population and economic activities.

The purpose of this study has been to downscale the GCMs outputs to future climate change scenarios at the local scale so that it is useful for local planning that takes into account changes in precipitation extremes and dry/wet spells. That is, in order to obtain projections as close as possible to the statistical properties and distribution function of the locally observed series of daily precipitation, through the use of a reference period with real data observed in situ.

As previous studies exist in this Mediterranean region [37,38] which include complete and homogeneous reference local observational series, work was done with the CDRD-HREIP-1955-2016 database as a source of local observed data information and the statistical downscaling of the global models for all the available observed series has been applied by using the LARS-WG method. Considering that this database provides more than 900 observed series in the study area, this method is computationally more efficient than other ones (e.g., with a dynamical approach).

\section{Study Site}

This study centers on two important river basins on the eastern facade of the Iberian Peninsula. In administration terms of regional water resources, they are known as the Júcar River Basin Authority (JHC) and the Segura River Basin Authority (SHC) (Figure 1). Both include the hydrographic basins of the Rivers Júcar and Segura, along with their subbasins and other adjacent smaller rivers, which are all included in the administrative management of the waters of the aforementioned main basins.

The study area is included in a Mediterranean climate area with its own characteristics, such as important torrential rain mechanisms and marked precipitation concentration and irregularity. These characteristics seem to be increasing with climate change $[21,38]$. 


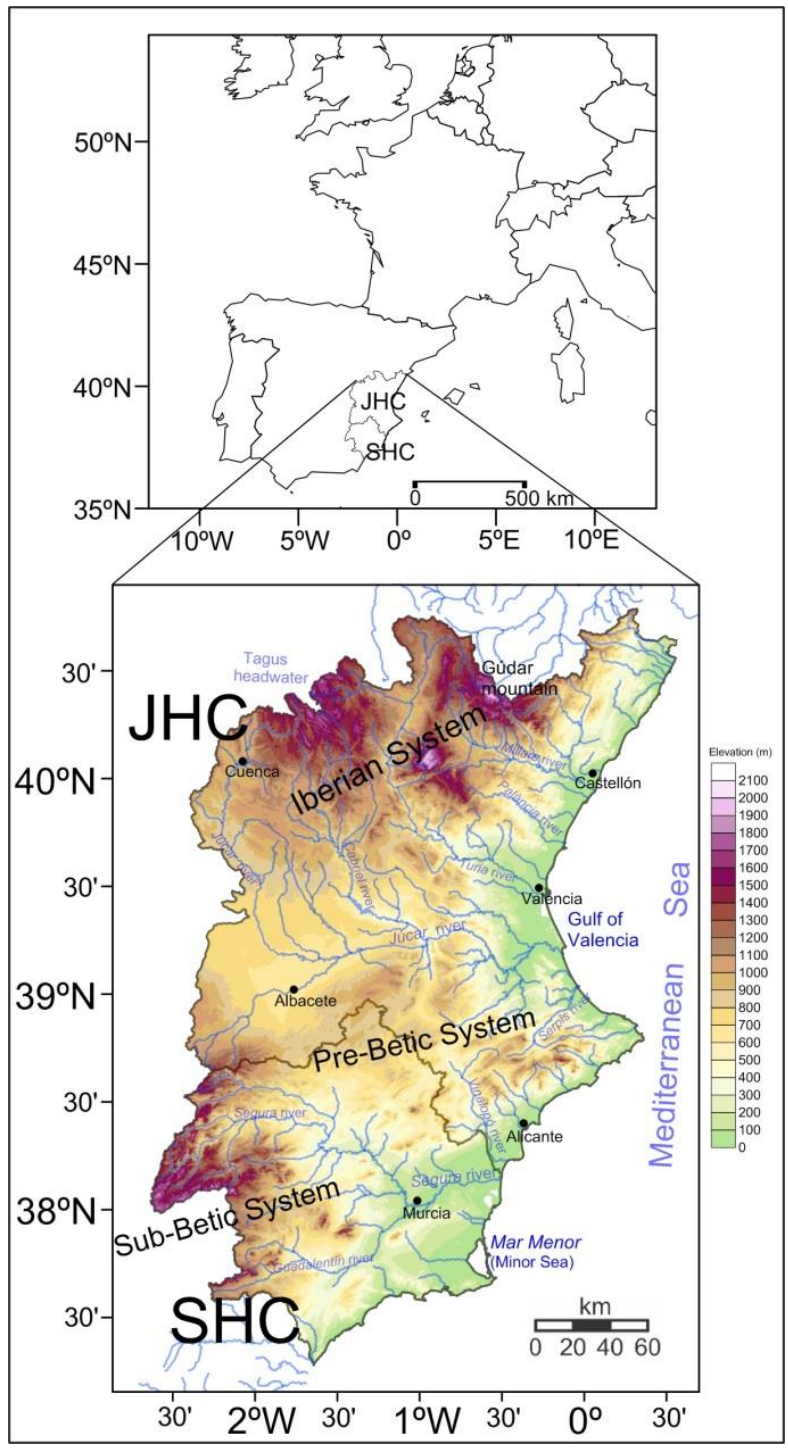

Figure 1. Spatial location map of study area: Júcar River Basin Authority, JHC, and Segura River Basin Authority, SHC.

\section{Materials and Methods}

\subsection{Climate Data Input}

The present study used the daily data of the precipitation observed in the study area to later perform the statistical downscaling of future climate change scenarios. The database employed for this purpose was the CDRD-HR-EIP-1955-2016 database [37,38]. This database covers quite a high spatial density (Figure 2) in the land where the Júcar and Segura hydrographic river basins lie. To conduct this work, methods were followed to fill in missing data and to homogenize, which allowed all the series to be rebuilt during a complete gap-free homogeneous and standard period (1955-2016). This makes it suitable for its use as a homogeneous base period for climate projections derived from statistical downscaling in the study area.

In any case, a 30-year period (1981-2010) was taken as the base period for downscaling global models because future projection scenarios will also represent 30-year variability. 


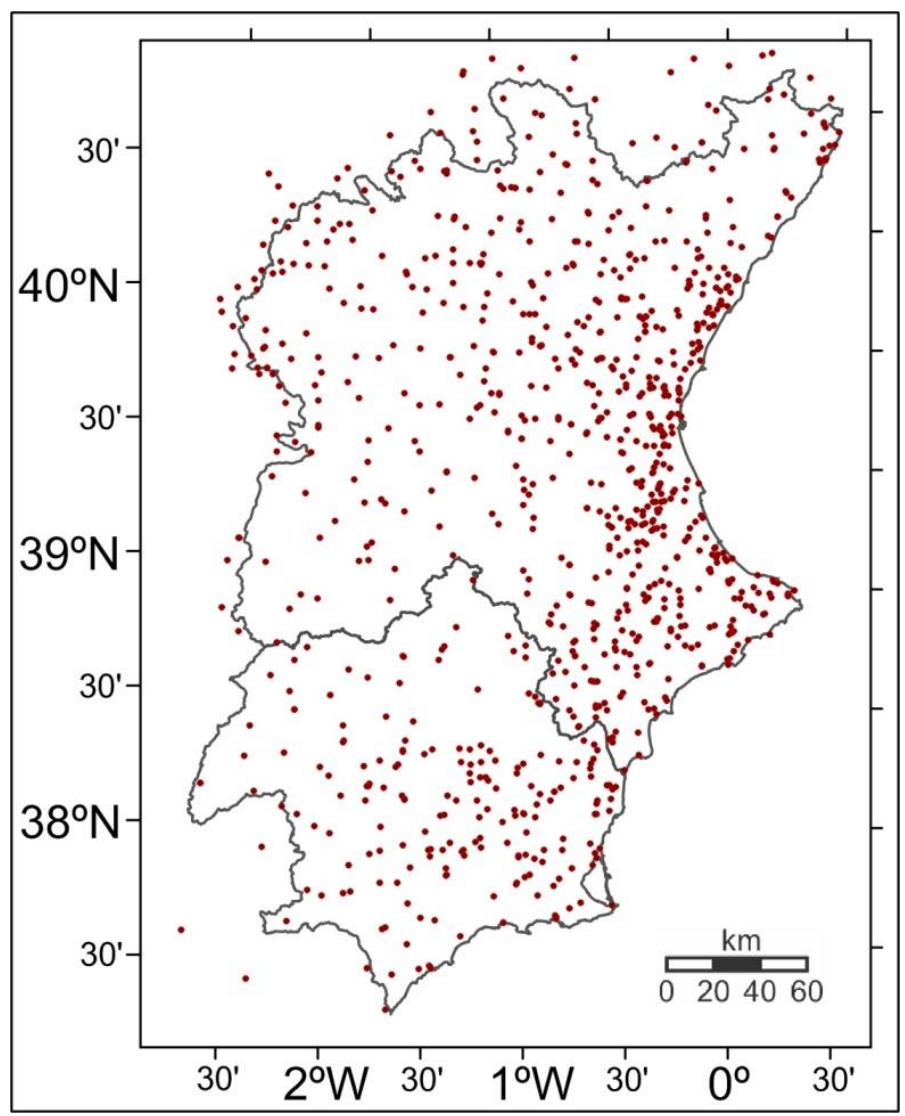

Figure 2. Location of stations with the observed precipitation series composing the CDRD-HR-EIP1955-2016 database, which are the source of the base period observed for the downscaling and climate projections in the present study.

\subsection{Statistical Downscaling of GCMs}

The Coupled Model Intercomparison Project (CMIP) is currently the result of the main international effort made to supply the scientific community with many global models to evaluate the climate's response to changes in radiative forcing in a projected climate change context in a future $\mathrm{CO}_{2}$ emissions scenario. Nevertheless, given the overall character and relatively thick mesh-type of these models, they do not suitably reflect local climate variability, or even regional variability [39]. Based on this premise, the most recent project phase underway, namely CMIP6, is proposed as an attempt to improve not only the regionalization of spatial change patterns but also estimations of descriptive indices of real climate variability and local extremes [40]. The use of downscaling is a generally more widespread tool to adapt the 'smoothed' outputs of global GCMs to the regional or local reality. For the local observed climate and its natural variability, adjustments by statistical downscaling are necessary, hence a temporal reference period during which the observed real series coincide/s with the periods covered by GCMs is used.

Many statistical downscaling methods exist, of which the most widespread and most tested ones are, perhaps, SDSM and LARS-WG as stochastic generators that simulate the variability of a given climate based on the climate observed during the reference period to which GCMs and specific $\mathrm{CO}_{2}$ scenarios are applied. The reason for using them lies in their comparatively lower computational cost than other techniques (e.g., ANNs) and their use does not entail a lower degree of uncertainty [41,42], which is most relevant when downscaling many local series.

Comparatively, the Long Ashton Research Station Weather Generator-LARS-WG [43] and the Statistical DownScaling Model-SDSM [44] have generally provided similar results in many studies from the time their first versions appeared to the present-day but this 
also depends on each study [45]. The study by Duan and Mei [46] is highlighted because it points out the slightly better capacity of LARS-WG to estimate extremes. Indeed, the study area is located in a Mediterranean climate where the proper characterization of precipitation extremes is important. Notwithstanding, LARS-WG has still to be employed in more recent studies [47].

The built-in packages of these downscaling techniques include models from the latest closed Coupled Model Intercomparison Project, that is, phase 5 (CMIP5). This means that they still do not include the GCMs from the most recent phase underway (CMIP6) for the calculations herein performed.

The present study employed the most recent version of the LARS-WG technique, LARS-WG 6.0, for a specific set of GCMs included in CMIP5. The LARS-WG downscaling technique was applied to all the available daily precipitation series (Figure 2) for which the base 1981-2010 period was used and daily projected series were produced for 30 years. These series are representative of two $\mathrm{CO}_{2}$ emissions scenarios-RCP 4.5 (medium stabilisation scenario) and RCP 8.5 (business as usual) and of three stages in the future: 2021-2040, 2051-2070 and 2081-2100. Although the generated series would be representative of the projected future periods with a 20-year time window, they would show the expected variability for the 30-year period in the same way as the base period.

As the downscaling of many GCMs for more than 900 series from the CDRD-HR-EIP1955-2016 database that are available in the study area represents considerable computing effort, four specific CGMs were selected to be downscaled. Those from CMIP5 with a higher native resolution in the study area were firstly selected according to the premise that this would better represent the Mediterranean mesoscale phenomena involved in intense rainfall [48]. They were CMCC-CM $\left(0.7^{\circ} \times 0.7^{\circ}\right.$ lat-lon res. $)$ and EC-EARTH $\left(1.1^{\circ} \times 1.1^{\circ}\right.$ lat-lon res.).

Moreover, a pair of GCMs with a somewhat lower resolution, namely HadGEM2-ES $\left(1.9^{\circ} \times 1.2^{\circ}\right.$ lat-lon res.) and ACCESS1-3 $\left(1.9^{\circ} \times 1.2^{\circ}\right.$ lat-lon res. $)$, were chosen based on different recommendations and results [49-52]. Notwithstanding, we generally found several arguments that make the best choice a difficult one.

Regarding CMCC-CM for this given GCM, it is worth stressing that the furthest future projection did not reach the year 2100 but 2090, and, therefore, the last projected period 2081-2100 was replaced with the 2071-2090 period only in this particular case.

Adapting the output obtained from downscaling with LARS-WG was evaluated with the generated output on the base period (1981-2010), which involved comparing the distribution of the simulated series to that observed during the base period. The KS (Kolmogorov-Smirnov) test was applied to estimate whether the series simulated for each season of the year had the same distribution as those observed. For winter, spring and autumn, the same distribution for this test was achieved in more than $98 \%$ of cases but we detected a slight overestimation of the total number of wet days. However, performance dropped to $80 \%$ in summer.

So, a decision was made to apply a bias correction process as the downscaling postprocess by following the ISIMIP method [53], https: / / rdrr.io/github/SantanderMetGroup / downscaleR/man/isimip3.html, accessed date (3 July 2021).

After applying the bias correction, the results with the same distribution according to the KS test improved and went beyond $92 \%$ of cases in summer, with practically $100 \%$ in the rest, and the slight overestimation for wet days was corrected. In relation to this point, it is worth pointing out that applying ISIMIP had a stronger impact on the frequency of wet days and maximum dry spell length on consecutive days with no rainfall obtained in the projections of future scenarios. Therefore, the results for dry spells could imply a higher degree of uncertainty in relation to the other variables.

The results obtained about extreme precipitations (pctile $\geq 99.9$ ) also indicated a higher degree of uncertainty which, in this case, relate to the actual estimated change in projections in the face of marked natural variability of these precipitations with time. Although the statistical $p$ value $(\alpha=0.05)$ of these changes between the base and the 
projected periods conferred the other change estimation's general reliability, it was only reliable in the located areas with a more marked change for extreme precipitations.

\section{Results}

After generating the 30-year daily precipitation series that represented periods 2021-2050, 2051-2070, 2081-2100, and emissions scenarios RCP 4.5 and RCP 8.5, the different results obtained with the downscaled series in the study area were spatially interpolated (IDW method). The obtained results were interpolated on the map of the studied basins. The following results were obtained:

- Percentage of change (\%) in the annual mean precipitation of the projected period in relation to the base period;

- Percentage of change (\%) in the mean seasonal precipitation of the projected period in relation to the base period. Complete months were considered as winter comprised December, January and February, spring included March, April and May, June, July and August formed summer, while autumn was formed by September, October and November;

- Absolute changes in the mean daily rainfall amounts falling over the $\geq 99.9$ percentile (extreme rainfalls) as regards to the base period;

- Change in the annual maximum spell length of consecutive days with no precipitation $\geq 1 \mathrm{~mm}$.

\subsection{Spatial Changes Projected for Annual Rainfall}

First of all, the percentage of change (Figure 3) for each projected period is shown in relation to the mean annual precipitation for the base period 1981-2010 for scenario 4.5 and all GCMs used in the study. Figure 4 depicts the same, but for scenario 8.5. On average, the results were statistically significant $(\alpha=0.05)$ with changes exceeding $8 \%$.

These results clearly move in the direction of greater influence of Mediterranean patterns for precipitation. These patterns are mainly Mediterranean cyclones or depressions that have deepened over the warm waters of the Mediterranean, along with humid winds from the east $[21,54]$. Specifically for scenario 4.5 , and for CMCC-CM to a greater extent, in the short to mid-term, we found that these areas were more affected by Mediterranean rainfall (littoral and central/southern pre-littoral, Gulf of Valencia, northeast side of the Pre-Betic System, Mar Menor area, etc.) with increased precipitation. Conversely, all areas inland, particularly towards the Iberian System part and the headwaters of the main rivers, especially in River Júcar, reductions in precipitation were observed. The territorial differences continued in the long term but the balance generally tipped in favor of loss of precipitation. EC-EARTH maintained the same spatial differences outline but, on the whole, it showed more losses than gains for precipitation in the short and mid-terms.

For scenario 8.5, the aforementioned spatial differences were also found but with a more general and quite drier background trend, especially for CMCC-CC in the long term with substantial losses inland (Júcar headwaters) and in the Vinalopó River corridor.

The results for the other two GCMs-ACCESS1-3 and HadGEM2-ES-are different in the background trend. Both in the short, mid and long terms, greater and more generalized loss of precipitation was found for ACCESS1-3 and HadGEM2-ES (greater long-term loss for RCP 8.5) but, once again, with the aforementioned spatial differences. 

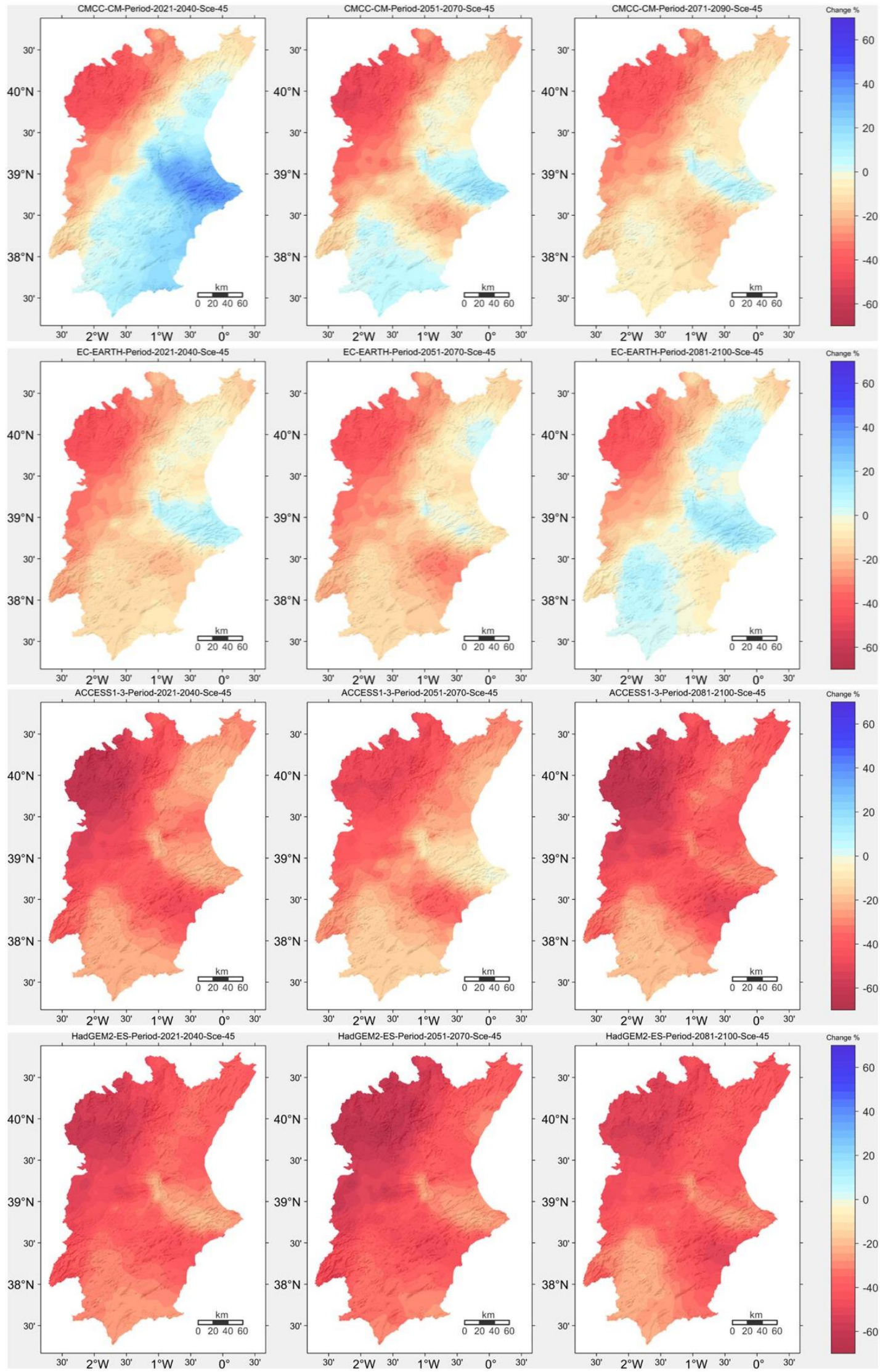

Figure 3. Spatial percentage changes in annual rainfall amounts downscaled from CMCC-CM (upper), EC-EARTH (middle up), ACCESS1-3 (middle down) and HadGEM2-ES (bottom). Projected for periods 2021-2040, 2051-2070 and 2081-2100 (available for 2071-2090 for CMCC-CM), and the scenario 4.5 . 

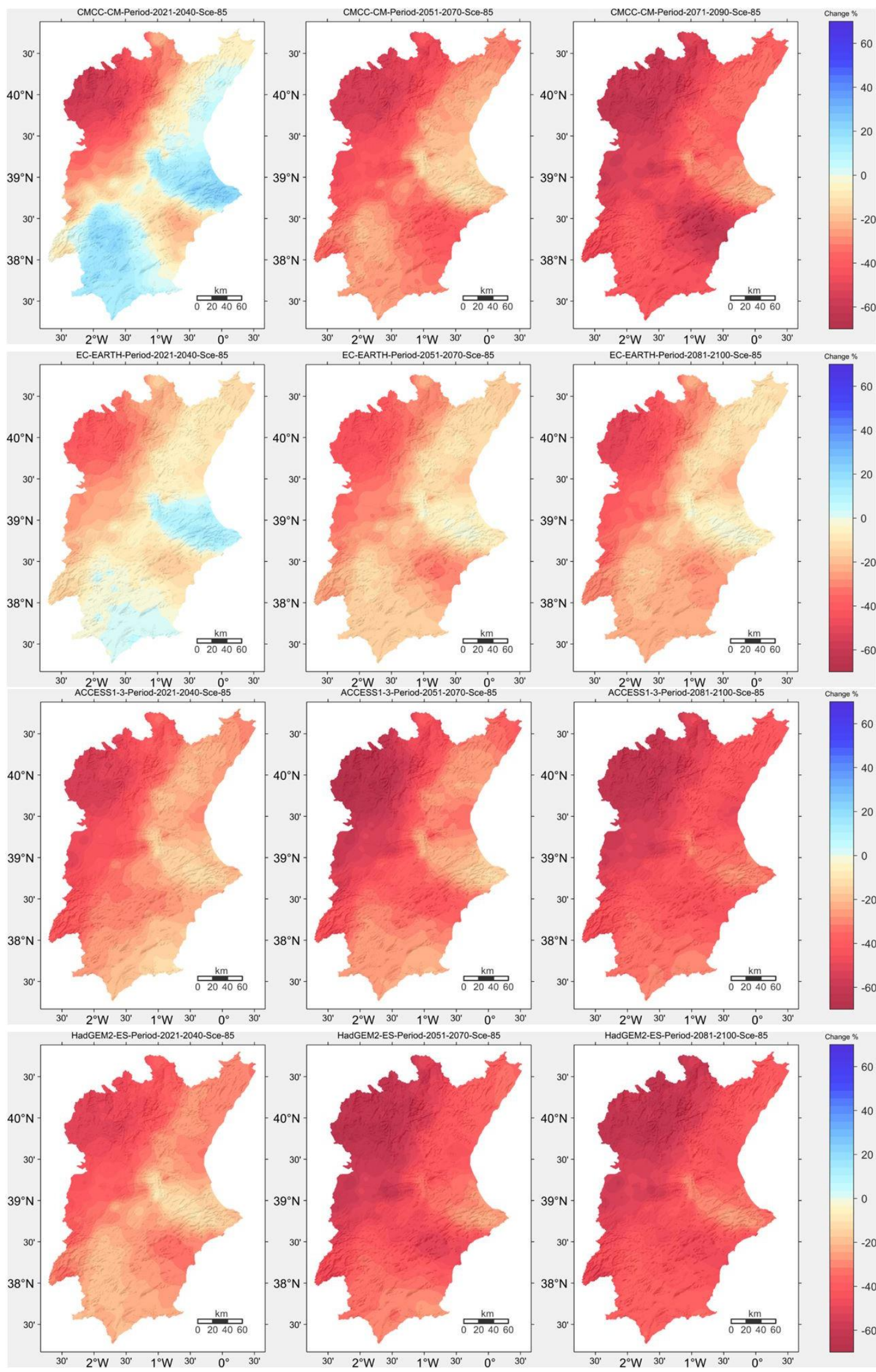

Figure 4. Spatial percentage changes in annual rainfall amounts downscaled from CMCC-CM (upper), EC-EARTH (middle up), ACCESS1-3 (middle down) and HadGEM2-ES (bottom). Projected for periods 2021-2040, 2051-2070 and 2081-2100 (available for 2071-2090 for CMCC-CM), and the scenario 8.5. 


\subsection{Spatial Changes Projected for Seasonal Rainfall}

In this case, the results showing seasonal changes were combined in two ensembles: HR with the two higher-resolution GCMs (CMCC-CM and EC-EARTH) and LR with the two lower-resolution GCMs (ACCESS 1-3 and HadGEM2). The seasonal distribution of precipitation on the hydrographical basin scale is essential for hydrological planning, especially due to its relation to farming. Thus, the higher resolution of the results and graphic outputs become a basic piece in affected lands.

We firstly show the result of the projected changes in total winter precipitation. Figures 5 and 6 illustrate RCP scenarios 4.5 and 8.5, respectively, for ensemble HR (top) and LR (bottom).

The same results, but for spring, are found in Figures 7 and 8, in Figures 9 and 10 for summer and in Figures 11 and 12 for autumn.

On average, these results were statistically significant $(\alpha=0.05)$ with changes exceeding $7 \%$ in winter, $10 \%$ in spring and $9 \%$ in autumn. Although we found major changes in summer, on average only changes over $25 \%$ were significant because precipitations were naturally scarce given the high interannual irregularity during this period. In all cases, the seasonal evolution of the precipitation results obtained higher percentages of reduced rainfall in the high emissions scenario RCP 8.5.
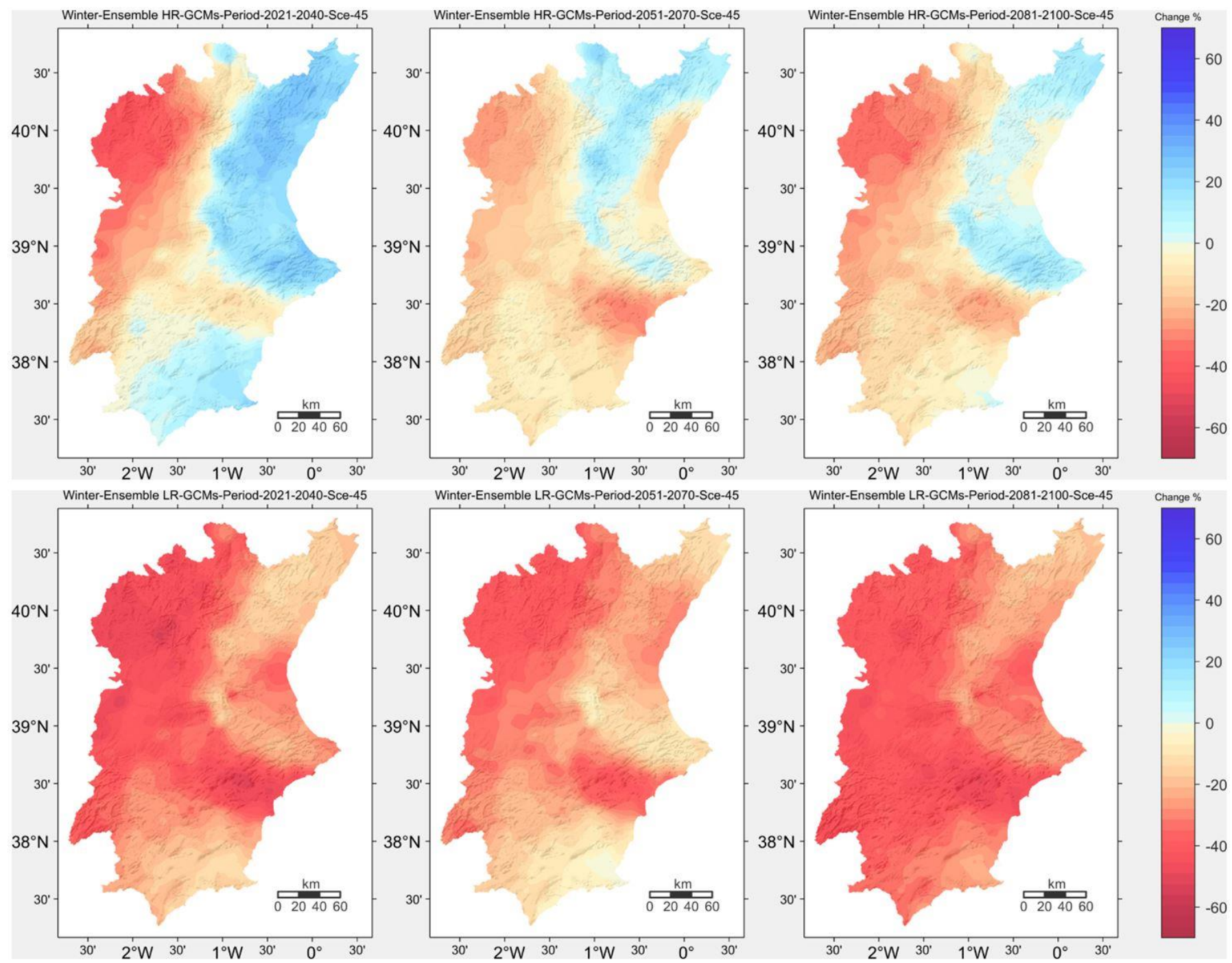

Figure 5. Spatial percentage changes in winter rainfall amounts downscaled from HR ensemble (upper) and LR ensemble (lower). Projected for periods 2021-2040, 2051-2070 and 2081-2100 (available for 2071-2090 for CMCC-CM case into HR ensemble), and the scenario 4.5 . 


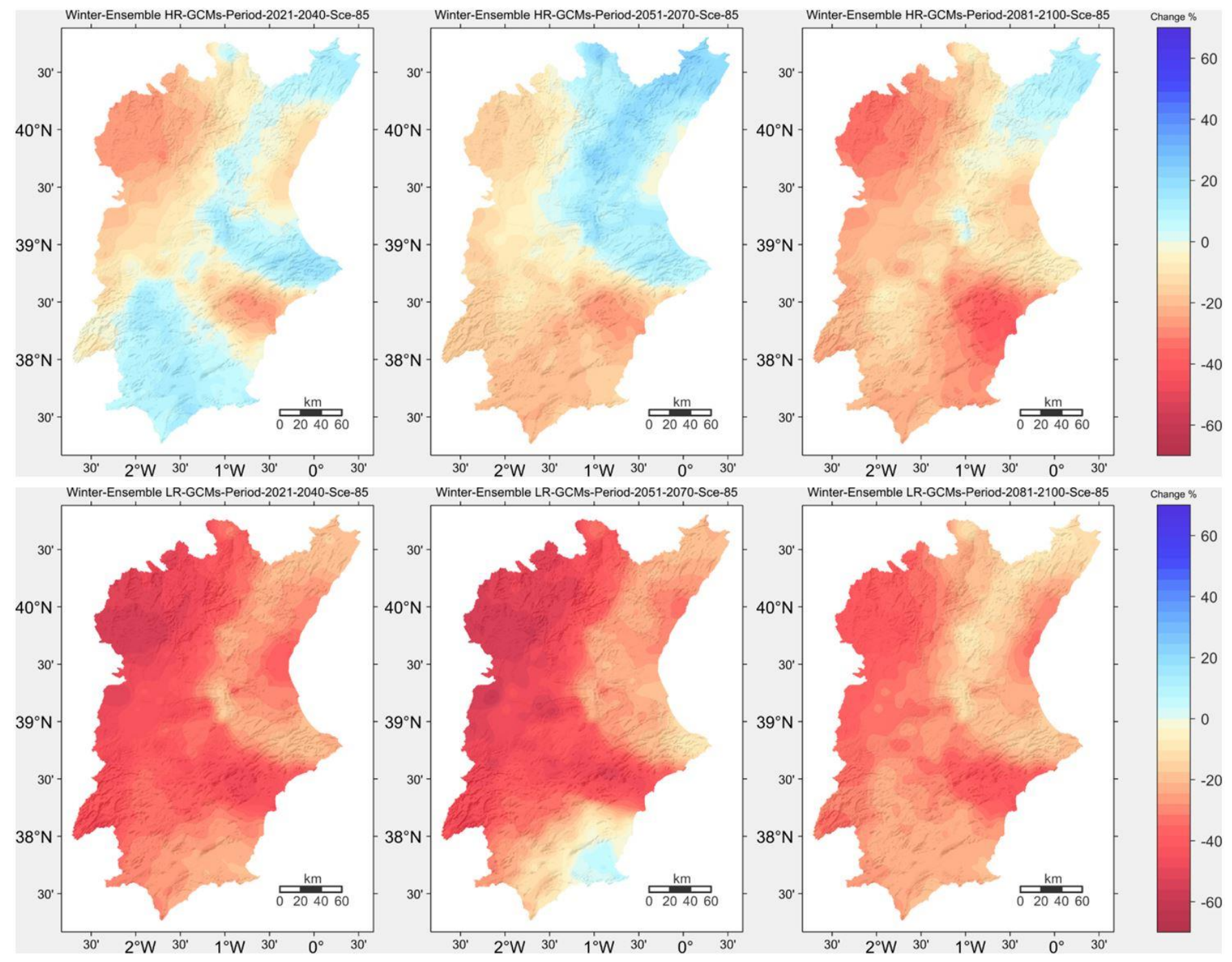

Figure 6. Spatial percentage changes in winter rainfall amounts downscaled from HR ensemble (upper) and LR ensemble (lower). Projected for periods 2021-2040, 2051-2070 and 2081-2100 (available for 2071-2090 for CMCC-CM case into HR ensemble), and the scenario 8.5 .

These results revealed a progressive reduction in winter precipitations towards the end of this century throughout the lands of the Júcar and Segura River Basins, and this reduction will be marked in the Júcar headwaters and in inland municipal areas of Alicante (Vinalopó, area between Valencia and Alicante). The increased precipitations found in the coastal areas near Júcar and Segura Rivers for the 2040 horizon would be related to the higher frequency of atmospheric circulations from the sea (surface east winds) in winter. However, this increase would then diminish on temporal horizons in the mid and long terms towards the end of this century. 


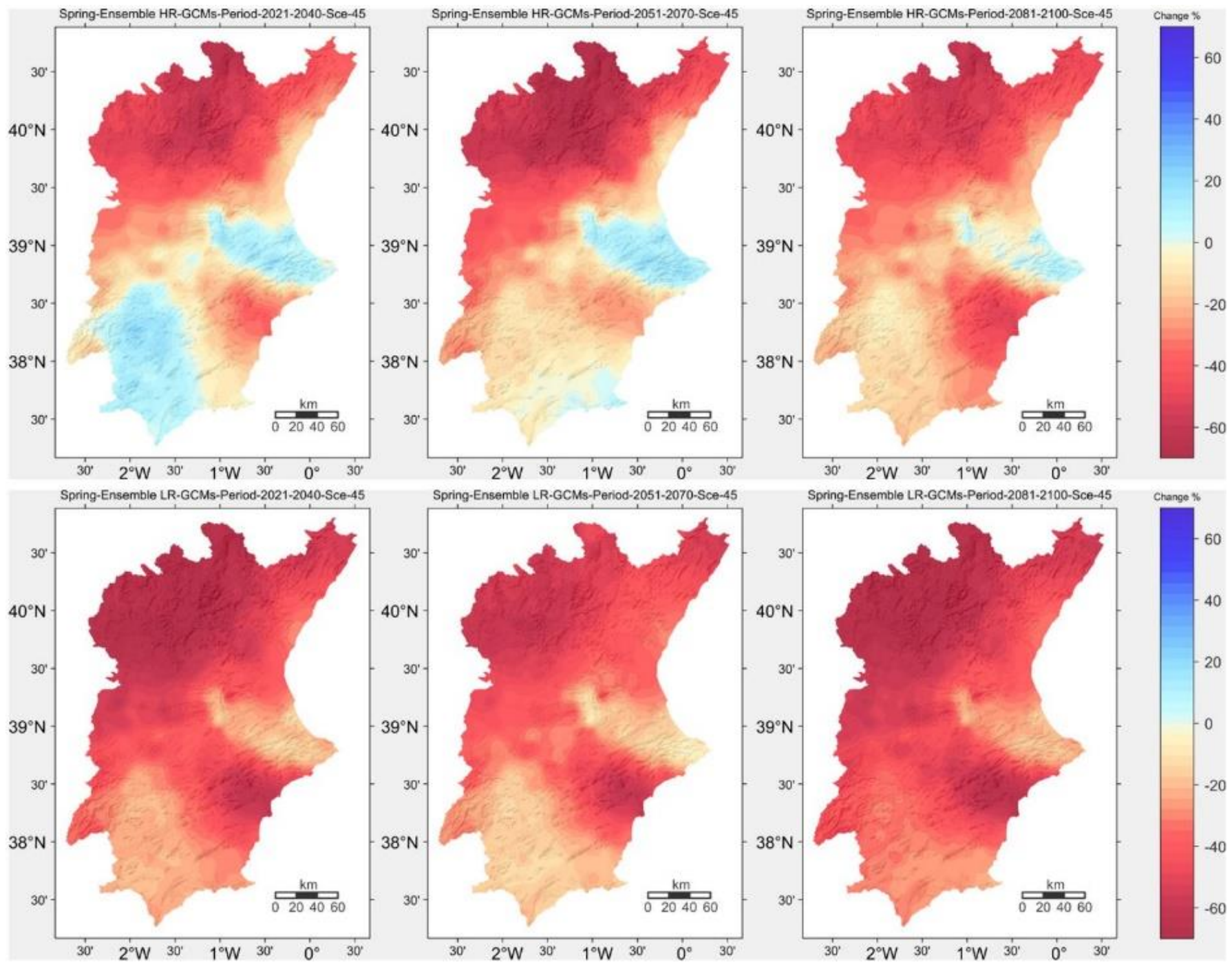

Figure 7. Spatial percentage changes in spring rainfall amounts downscaled from HR ensemble (upper) and LR ensemble (lower). Projected for periods 2021-2040, 2051-2070 and 2081-2100 (available for 2071-2090 for CMCC-CM case into HR ensemble), and the scenario 4.5 .

The most negative results appeared in spring in the Júcar headwaters. A generally lowering trend in spring was found in the Júcar and Segura River Basins in the mid (2015-2070) and long (2081-2100) terms. Only the littoral area that lies south of Valencia and the north area of Alicante presented a slight increase in the short term (2021-2040) following the aforementioned annual precipitation trend in this same territory. 


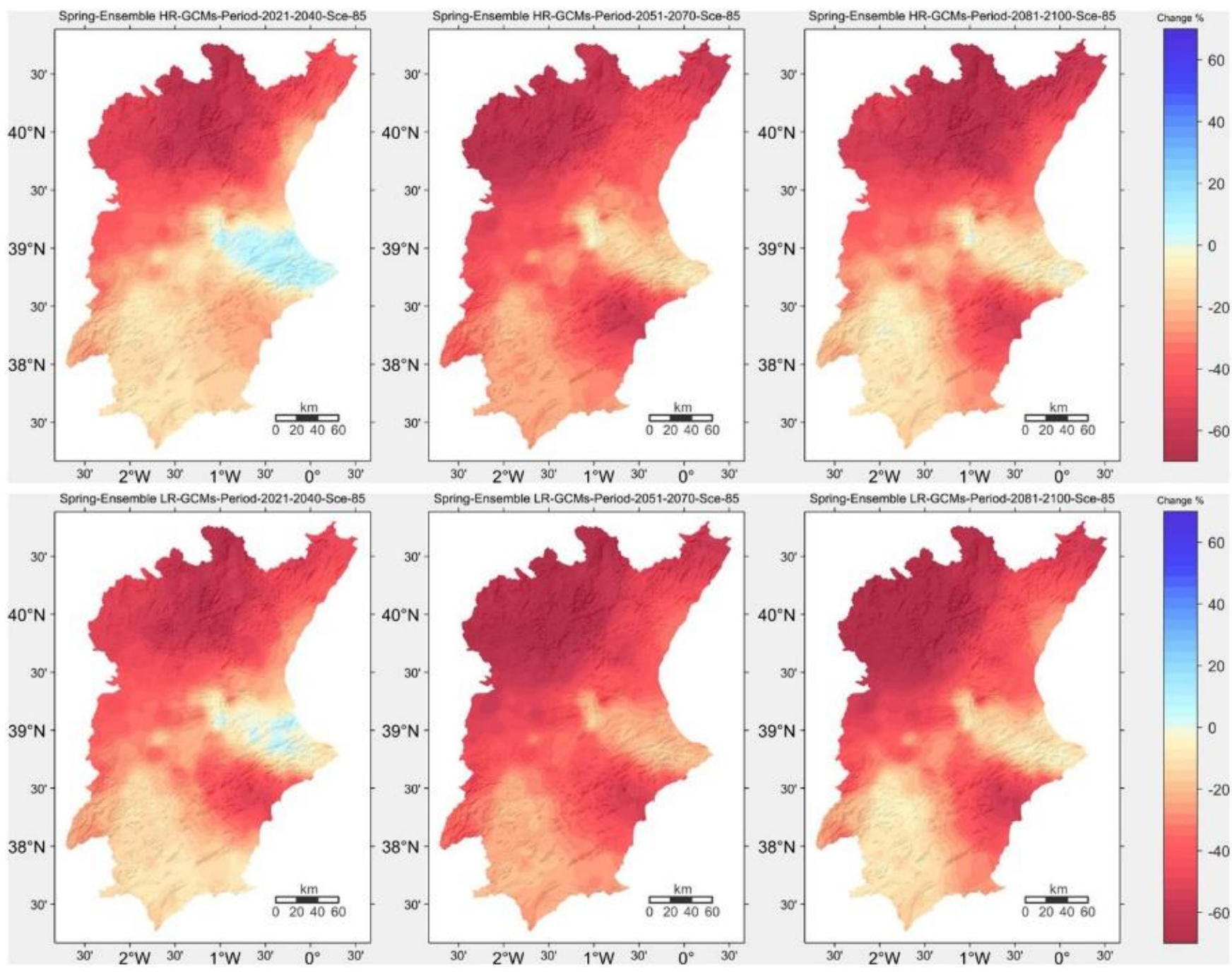

Figure 8. Spatial percentage changes in spring rainfall amounts downscaled from HR ensemble (upper) and LR ensemble (lower). Projected for periods 2021-2040, 2051-2070 and 2081-2100 (available for 2071-2090 for CMCC-CM case into HR ensemble), and the scenario 8.5 .

The least rainy season in the Júcar and Segura River Basins was summer regarding the most frequent synoptic pattern (anticyclone subsidence) that affected the Iberian Peninsula. The results herein obtained revealed a marked trend towards scarcer summer rainfall in the mid and long terms. Nevertheless, the increase noted in some littoral areas of Valencia, Alicante and Murcia (Mar Menor) stands out in relation to an increase in summer convective processes (storms), whose dynamics were closely related to Mediterranean Sea water thermal performance in summer [55]. However, in this case, only the rainfall decreases from inland are statistically significant $(\alpha=0.05 \approx$ changes $>25 \%)$. This is also confirmed by other studies about the Mediterranean area, such as Greco et al. [56]. 


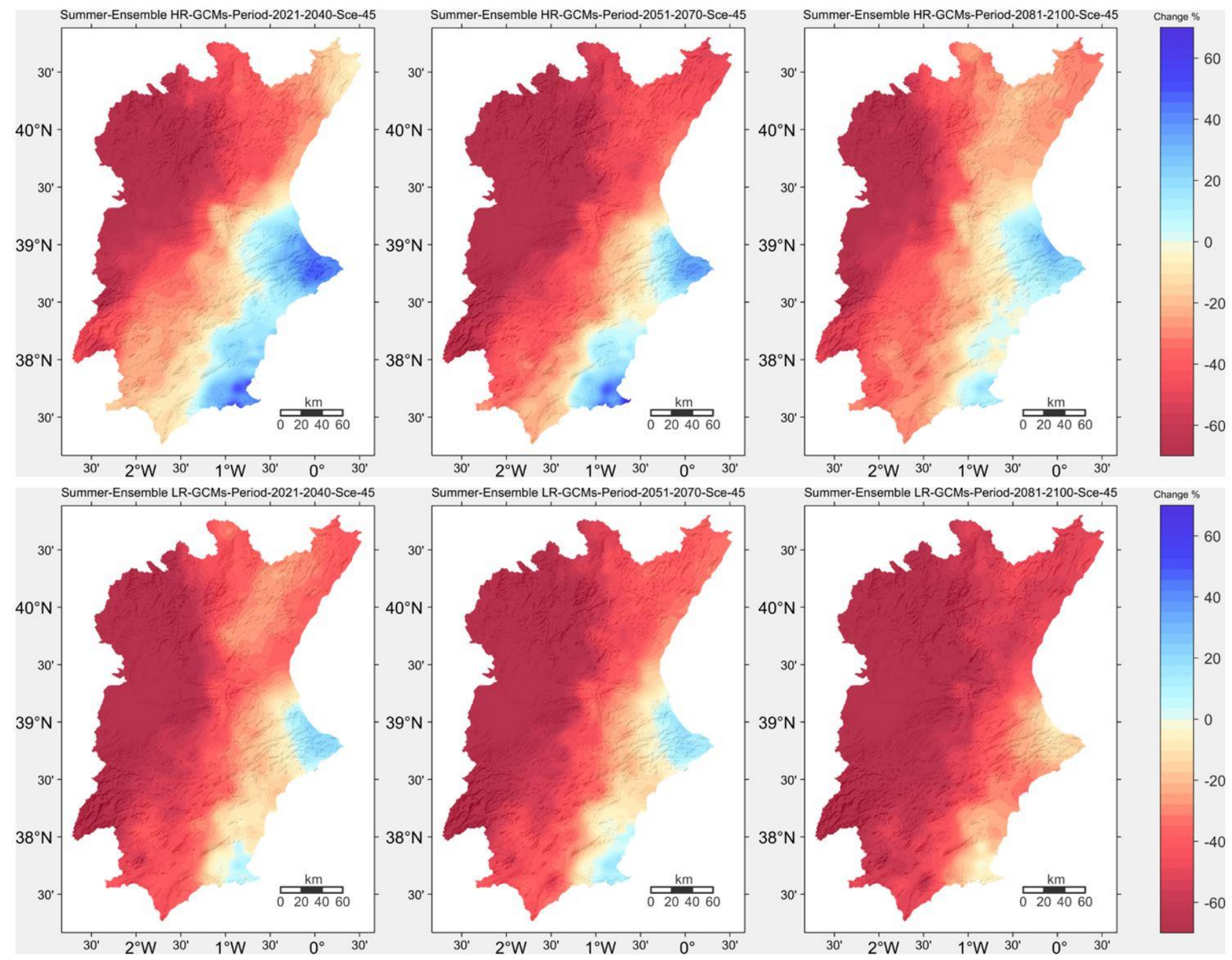

Figure 9. Spatial percentage changes in summer rainfall amounts downscaled from HR ensemble (upper) and LR ensemble (lower). Projected for periods 2021-2040, 2051-2070 and 2081-2100 (available for 2071-2090 for CMCC-CM case into HR ensemble), and the scenario 4.5 . 


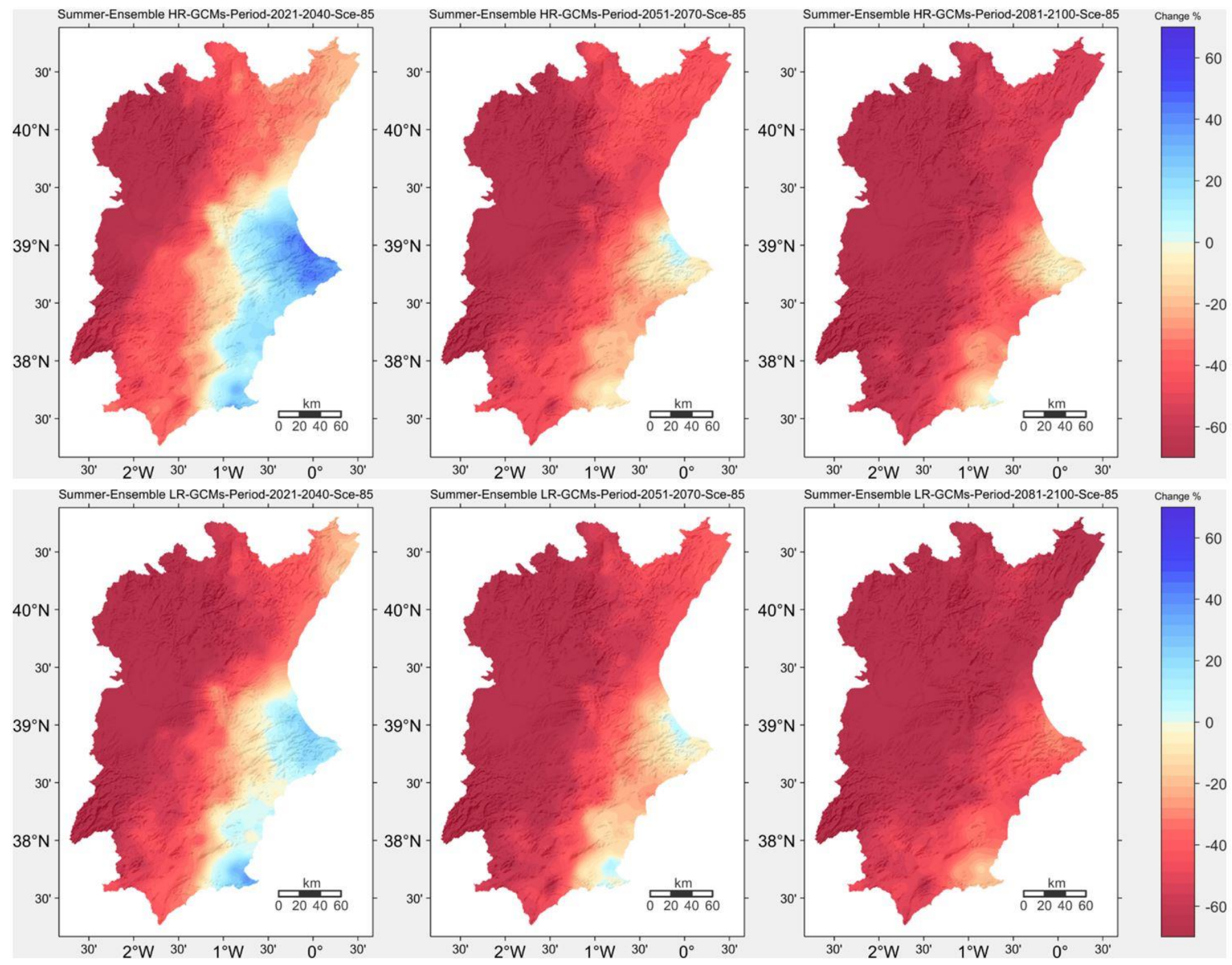

Figure 10. Spatial percentage changes in summer rainfall amounts downscaled from HR ensemble (upper) and LR ensemble (lower). Projected for periods 2021-2040, 2051-2070 and 2081-2100 (available for 2071-2090 for CMCC-CM case into HR ensemble), and the scenario 8.5 .

The most outstanding result obtained for autumn was an increase in precipitations for the 2021-2040 horizon, mostly on the land where the Júcar and Segura River Basins are found, which became fuzzier towards the end of the century. The only places showing reduced autumn rainfall were the Júcar headwaters, the southern littoral of Alicante and most of the Murcia littoral, even for the 2021-2040 horizon in the low emissions scenario RCP 4.5, which became more marked in the high emissions scenario (8.5). However, in this case the repeated pattern of decrease in the interior, especially NW, and increase, or smaller decrease, in the south of Valencia-north of Alicante is less clear than in the other seasons. 


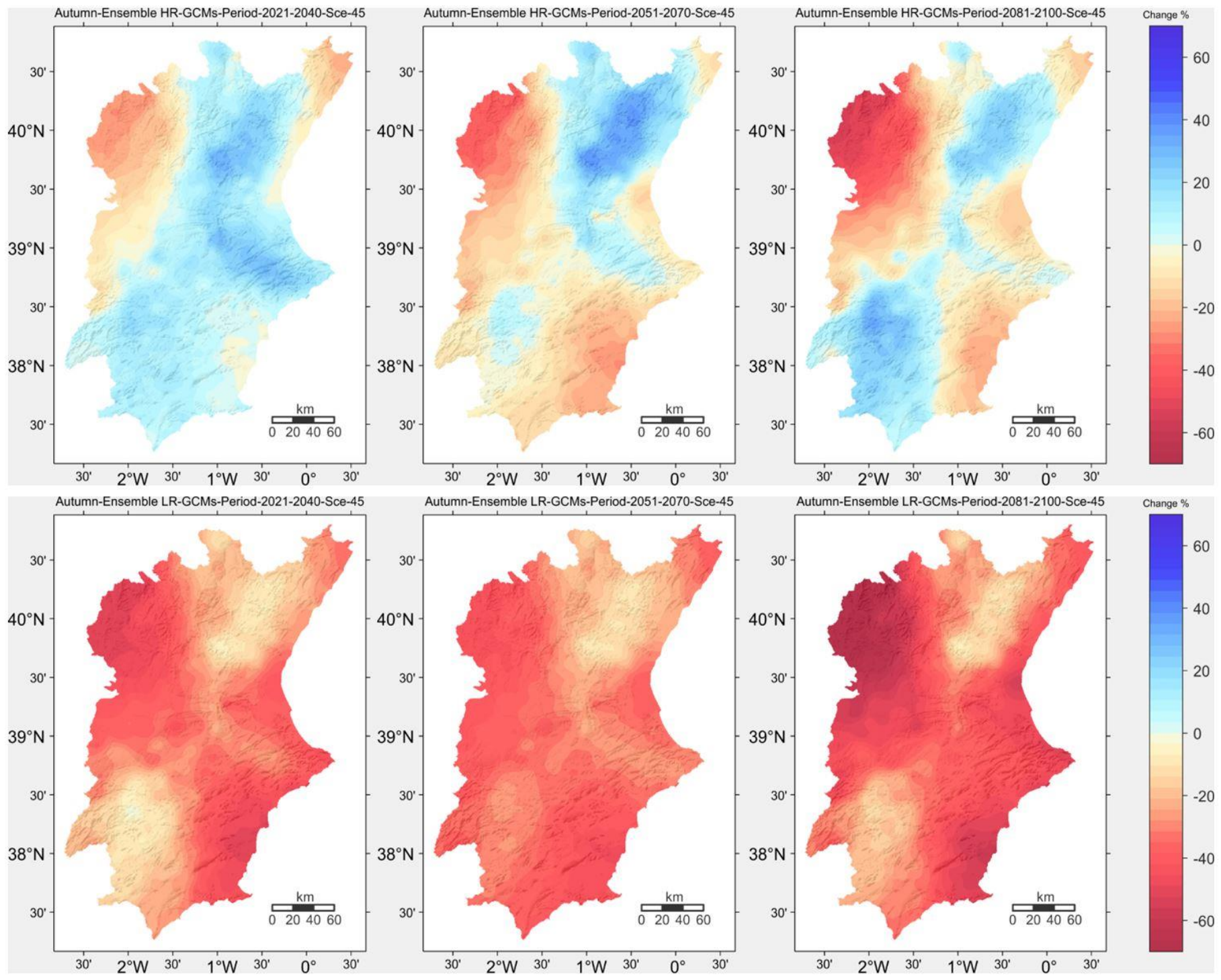

Figure 11. Spatial percentage changes in autumn rainfall amounts downscaled from HR ensemble (upper) and LR ensemble (lower). Projected for periods 2021-2040, 2051-2070 and 2081-2100 (available for 2071-2090 for CMCC-CM case into HR ensemble), and the scenario 4.5. 


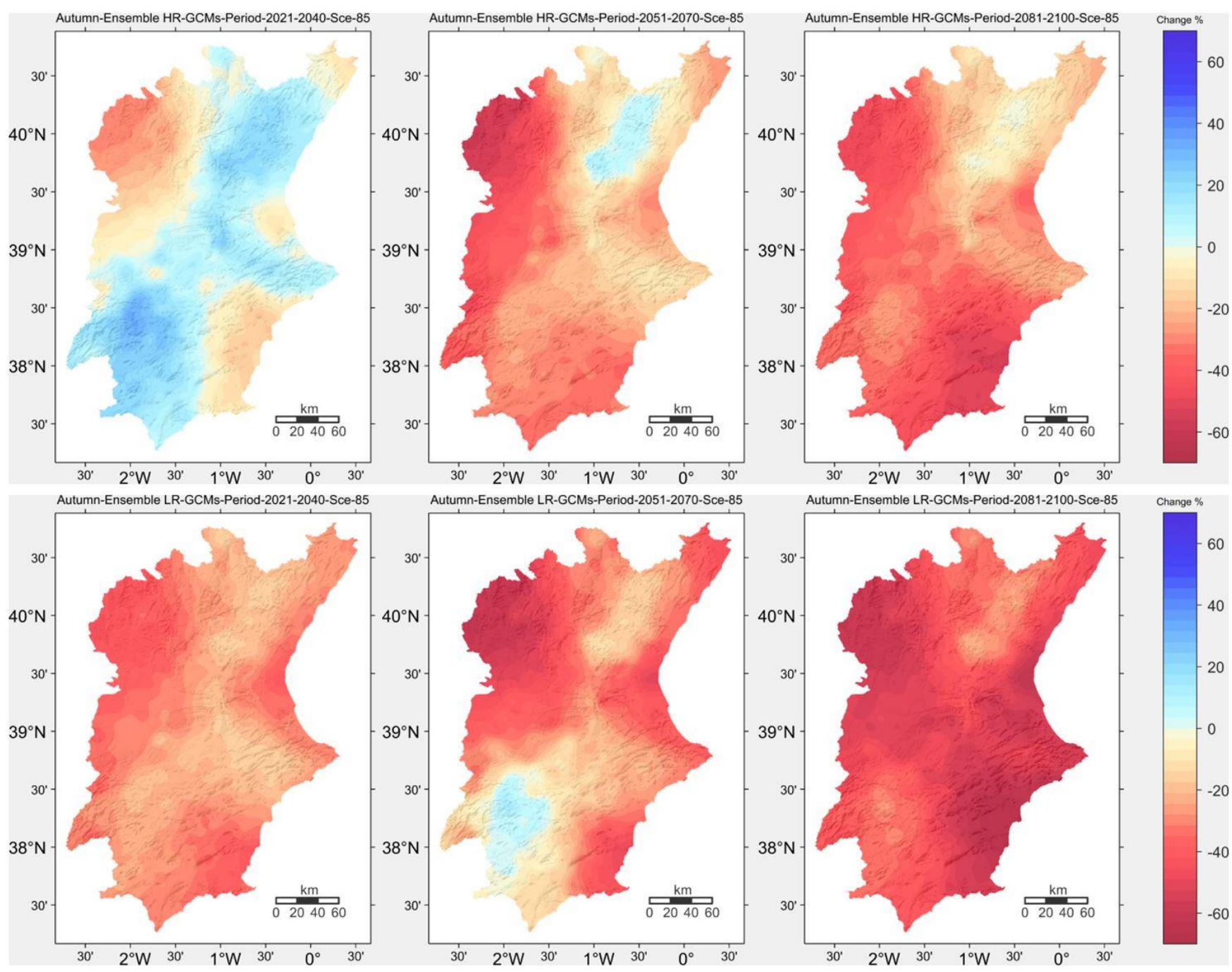

Figure 12. Spatial percentage changes in autumn rainfall amounts downscaled from HR ensemble (upper) and LR ensemble (lower). Projected for periods 2021-2040, 2051-2070 and 2081-2100 (available for 2071-2090 for CMCC-CM case into HR ensemble), and the scenario 8.5 .

\subsection{Spatial Changes Projected for Extreme Rainfall (Pctile $\geq$ 99.9)}

The obtained results shows the absolute change projected for the mean daily precipitation of those events that fall within the $\geq 99.9$ percentile, estimated as $\mathrm{mm} /$ day. Here the only result shown was that obtained with the higher-resolution GCMs (CMCC-CM and EC-EARTH) for RCP scenarios 4.5 (Figure 13) and 8.5 (Figure 14), which were more suitable for estimating extremes.

In this case, changes were only statistically significant on average when changes exceeded $30 \mathrm{~mm} /$ day. But it should be noted that rainfall extremes in the region are often in excess of 100 or even $200 \mathrm{~mm}$ per day. 


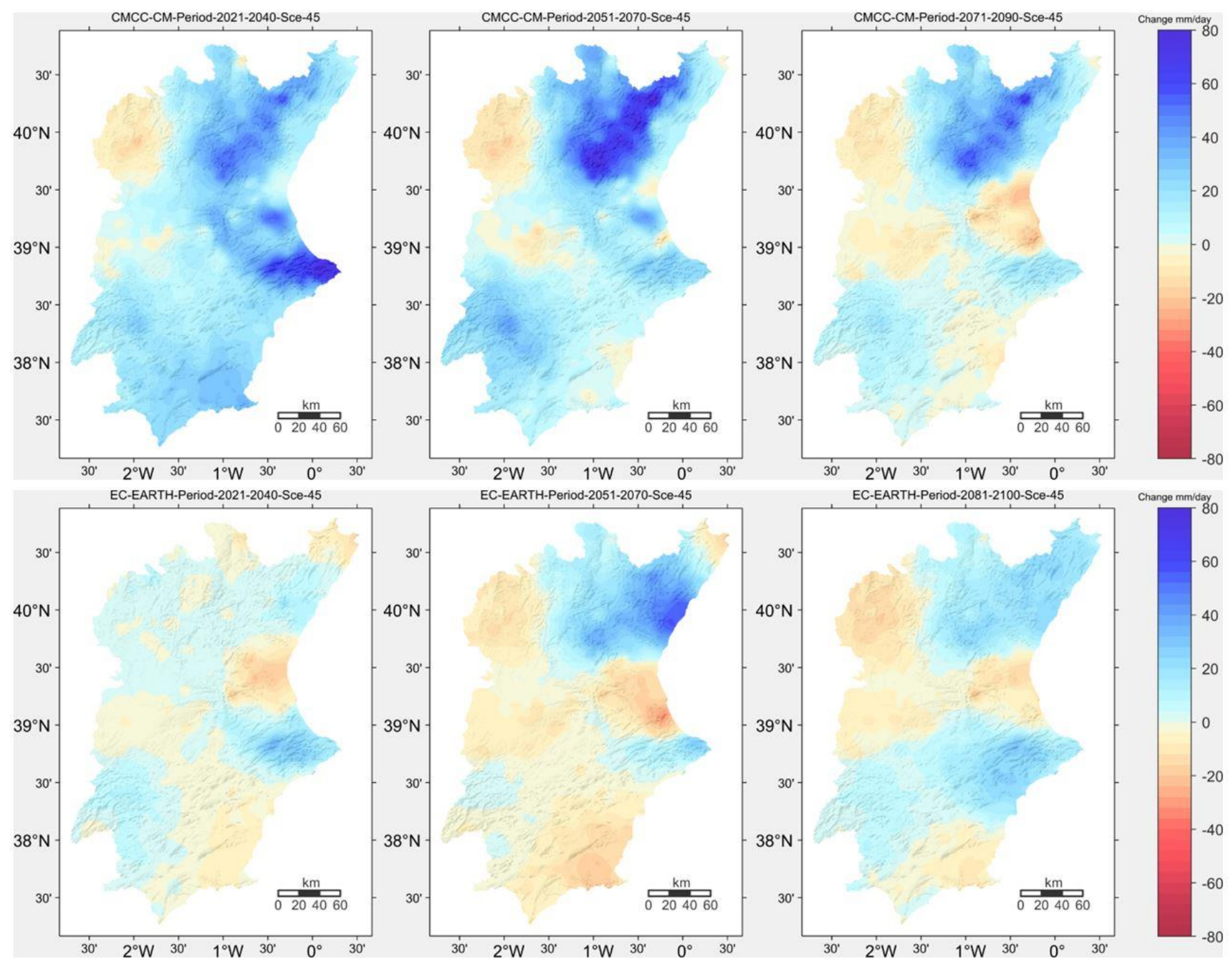

Figure 13. Spatial absolute changes in mean daily rainfall amounts falling over the percentile $\geq 99.9$ (extreme rainfalls). Downscaled from CMCC-CM (upper) and EC-EARTH (lower) models. Projected for periods 2021-2040, 2051-2070 and 2081-2100 (available for 2071-2090 for CMCC-CM), and the scenario 4.5.

In both the short and mid-terms, and with scenario 4.5, the CMCC-CM model (and EC-EARTH to a lesser extent) indicated increased torrential rain in certain areas, such as the NE part of the Pre-Betic System in the short term and the eastern part of the Iberian System in the mid-term. Conversely, in the long term, the diminishing trend was greater in scenario 8.5 . 


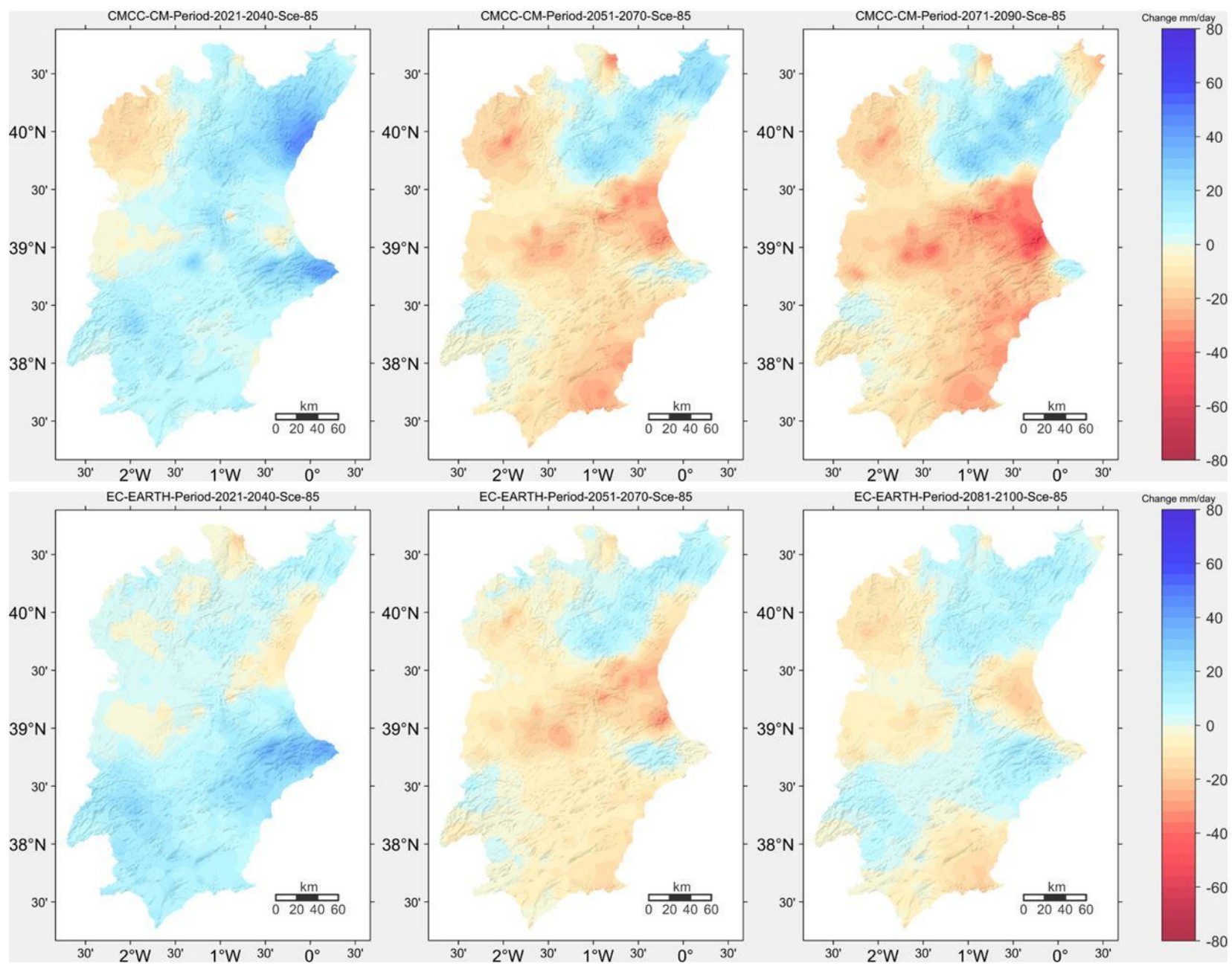

Figure 14. Spatial absolute changes in mean daily rainfall amounts falling over the percentile $\geq 99.9$ (extreme rainfalls). Downscaled from CMCC-CM (upper) and EC-EARTH (lower). Projected for periods 2021-2040, 2051-2070 and 2081-2100 (available for 2071-2090 for CMCC-CM), and the scenario 8.5.

\subsection{Spatial Changes Projected for Annual Maximum Dry Spell Length}

A change estimation for the annual maximum dry spell length on consecutive days without precipitation over a minimum threshold acts as an indicator of an increased drought trend existing.

The results obtained for all GCMs and scenarios 4.5 and 8.5 are shown respectively in Figure 15 (RCP 4.5) and Figure 16 (RCP 8.5). On average, these results were statistically significant when changes exceeded 17 days.

Regarding the statistically significant data, increments in dry spells length predominated, while minor reductions in certain areas were not statistically significant in general. The increase in dry spell length was clearly more outstanding inland, more long term and in scenario 8.5 . 

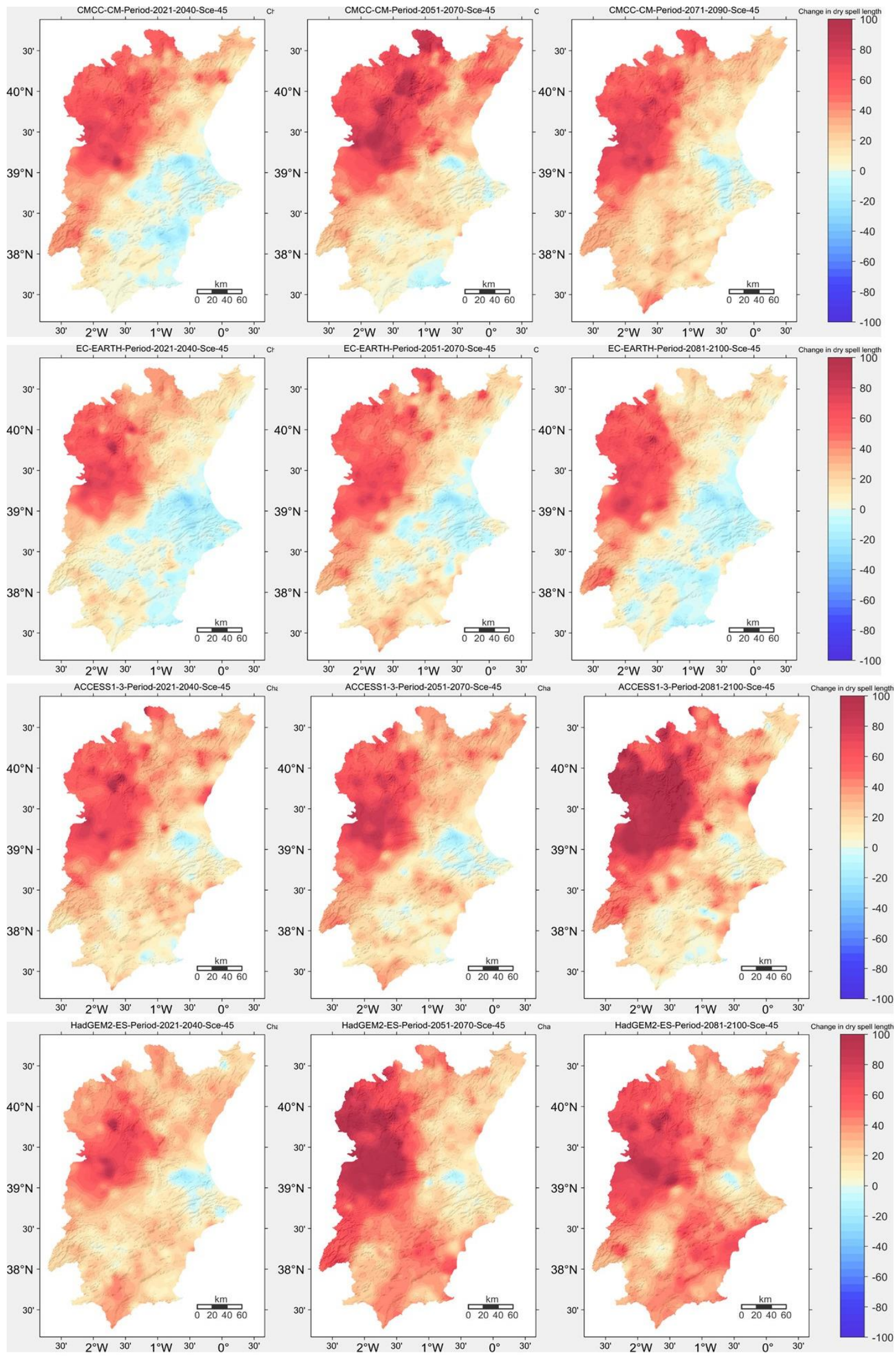

Figure 15. Spatial percentage changes in annual maximum dry spell length, given in days length with $p<1 \mathrm{~mm}$ - downscaled from CMCC-CM (upper), EC-EARTH (middle up), ACCESS1-3 (middle down) and HadGEM2-ES (bottom) models. Projected for periods 2021-2040, 2051-2070 and 2081-2100 (available for 2071-2090 for CMCC-CM), and the scenario 4.5. 

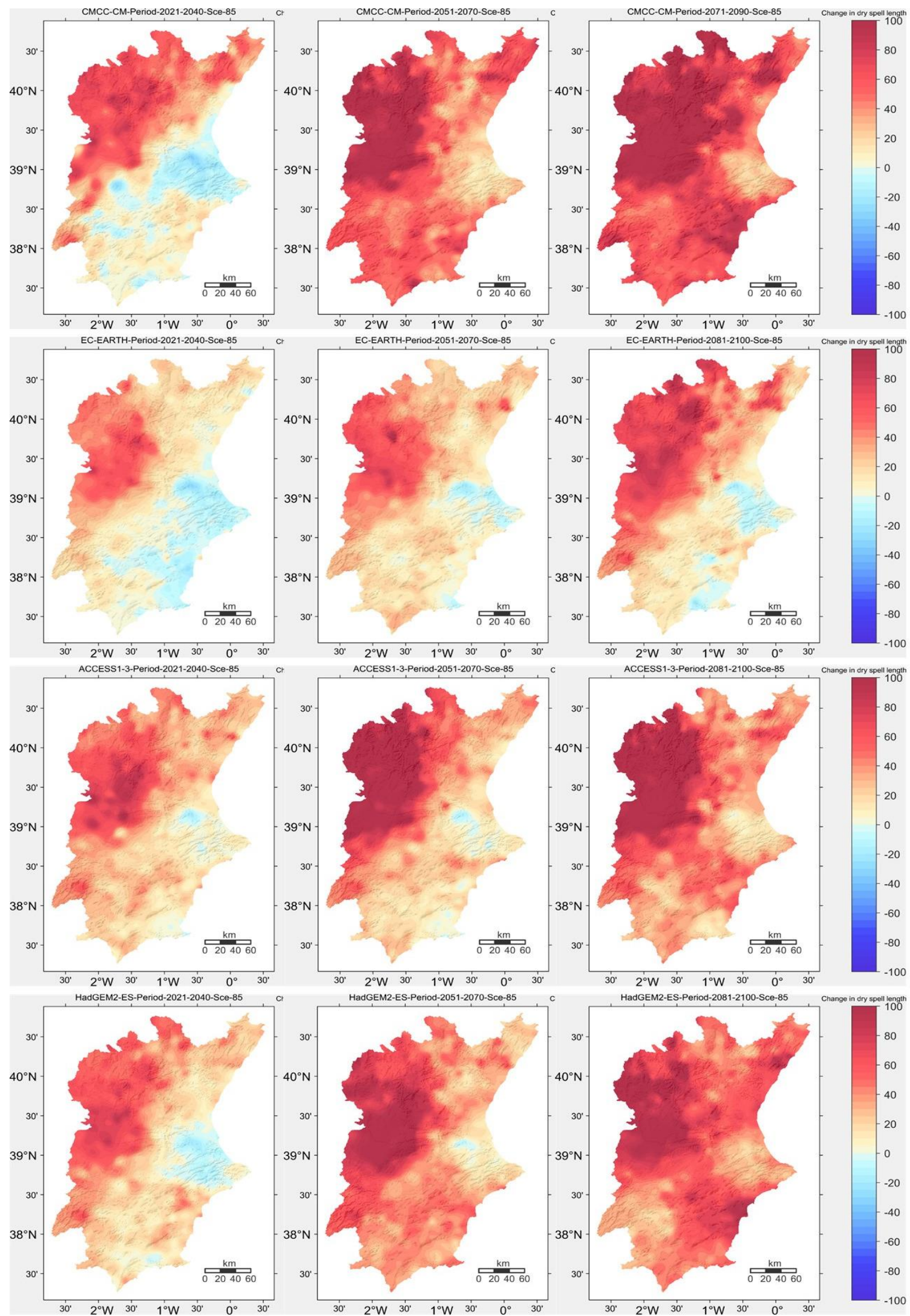

Figure 16. Spatial percentage changes in annual maximum dry spell length, given in days length with $p<1 \mathrm{~mm}$ - downscaled from CMCC-CM (upper), EC-EARTH (middle up), ACCESS1-3 (middle down) and HadGEM2-ES (bottom) models. Projected for periods 2021-2040, 2051-2070 and 2081-2100 (available for 2071-2090 for CMCC-CM), and the scenario 8.5. 


\section{Discussion}

Previous analyses performed in the study area for the 1955-2016 period pointed out negative trends towards a reduction in the annual precipitations over the headwaters of both the Segura and Júcar basins, especially inland of the Júcar basin [38]. In addition, Miró et al. [57,58] point out a greater trend towards higher temperatures inland. For the JHC, some spaces clearly showed less precipitation (high stretch and middle/low basins of Rivers Turia and Júcar, and the basin of Vinalopó and central coast region of Alicante), along with others where increased rainfall has been recorded (border region between the northeast of Alicante and southeast of Valencia) and the eastern sector of Pre-Betic mountains in Alicante province). These same spatial patterns are observed in the present analysis for the projections made through the high spatial resolution models (CCMCC-CM and EC-EARTH) for scenario 4.5 (comparison between Figures 3 and 17). In both, the area between the lower Júcar zone and north of the Alicante province (eastern side of Pre-Betic) stood out for the forecasted increase in annual precipitations, which was more marked in the short and mid-terms (horizon 2040). The reduction in annual precipitations in the rest of the study area was also noteworthy and the projection made for the high stretch of Rivers Júcar and Turia is worrying for hydrological planning purposes.

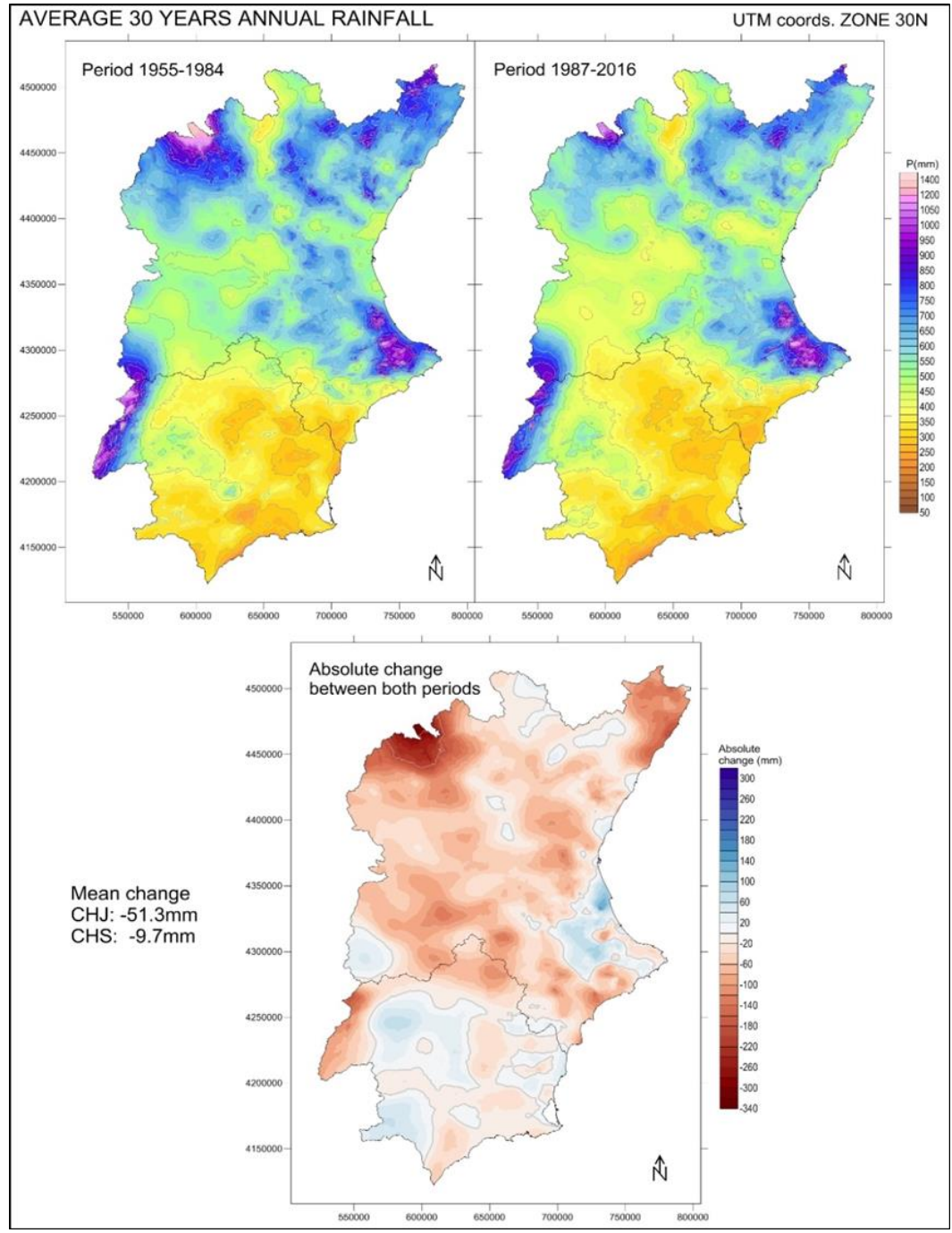

Figure 17. Source: Miró et al. [38].

This increase of the total annual precipitation in the climate projection for certain areas is not related to the enhanced regularity of precipitation episodes all year long but to 
growing intense daily rain episodes. This process has already been pointed out in former analyses [38] of recorded trends with precipitation data collected during different periods (1955-1984 to 1987-2016) for wide littoral areas, particularly in the Júcar demarcation (Figure 18). High-resolution models maintained this trend on the littoral stretch in the mid and long terms for scenario 4.5. This trend was specified for scenario 8.5. Downscaling the higher-resolution models (CMCC_CM and, to a lesser extent, EC-EARTH) indicated a rise in mid-term torrential rain (2021-2070) in those areas most affected by the Mediterranean cyclogenesis phenomenon, which would lower in the long term (2100). This is coherent with the analysis about the increased intensity of precipitations performed for the Mediterranean littoral overall [59].

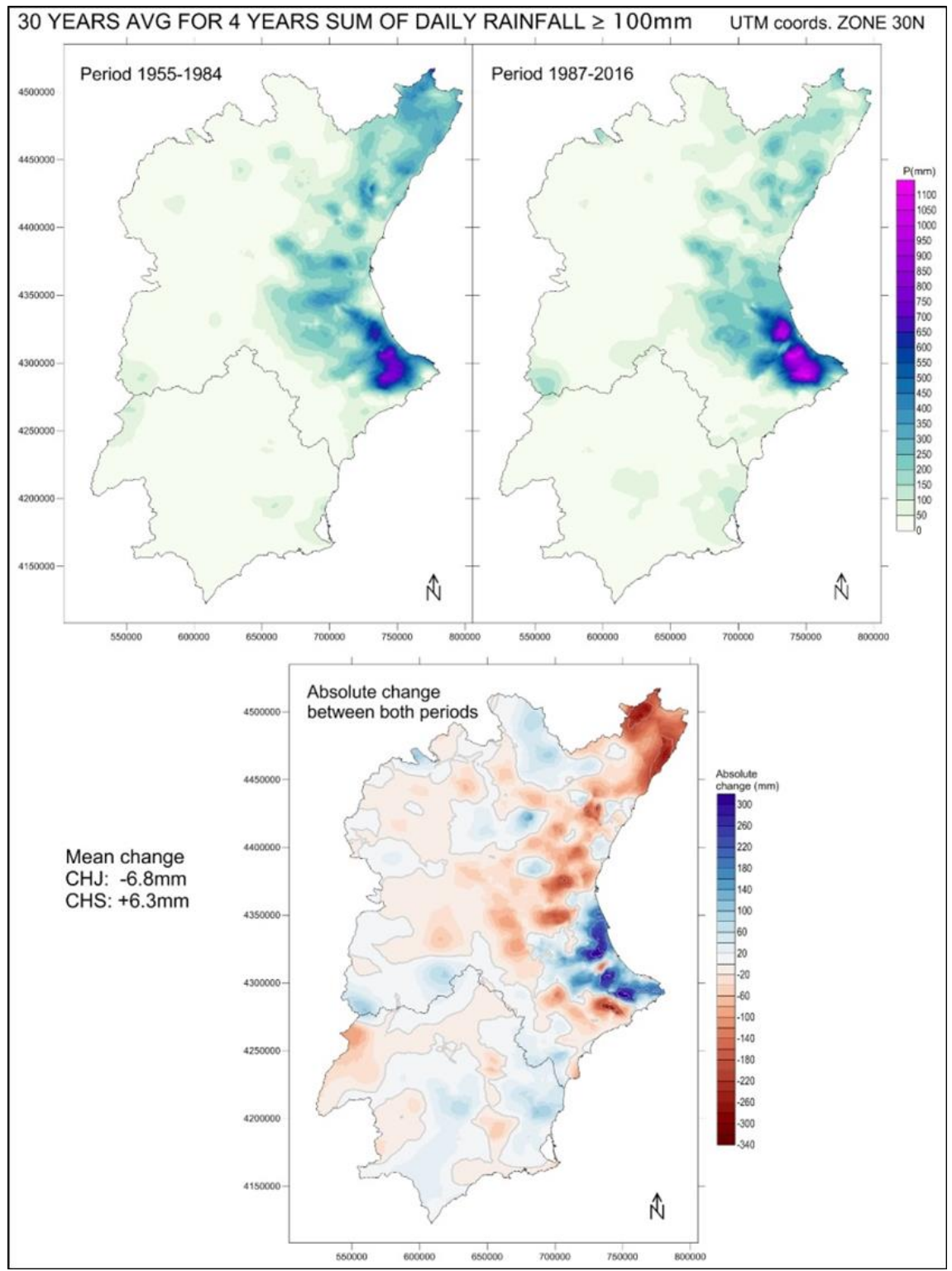

Figure 18. Source: Miró et al. [38].

In general terms, all these results indicated, to a greater extent for the low-resolution models than the high-resolution ones, a prolonged duration of dry spell episodes or the number of dry days in the long term, with more heterogeneities in the mid-term. This trend is also consistent with the results obtained on the generalized trend towards increasing dry spells in the historical series analyzed in [38]. 
For seasonal changes, a very marked reduction in precipitations was seen in the summer semester, which coincides with the results obtained by other authors for our study area $[60,61]$

The climate modeling results, performed in high spatial resolution, allowed detailed scalar approaches which, as previously indicated, have started being used for spatial planning (regional and local). Benidorm (which lies SE of the Júcar River Basin) has drawn up a plan to adapt to climate change by incorporating the high-resolution ensemble results for scenarios RCP 4.5 and 8.5 (Figure 19). The results revealed more daily precipitations over $100 \mathrm{~mm}$ in both scenarios RCP4.5 and RCP 8.5 in the short term (2021-2040). This implies having to plan current rainfall evacuation conditions in urban areas.

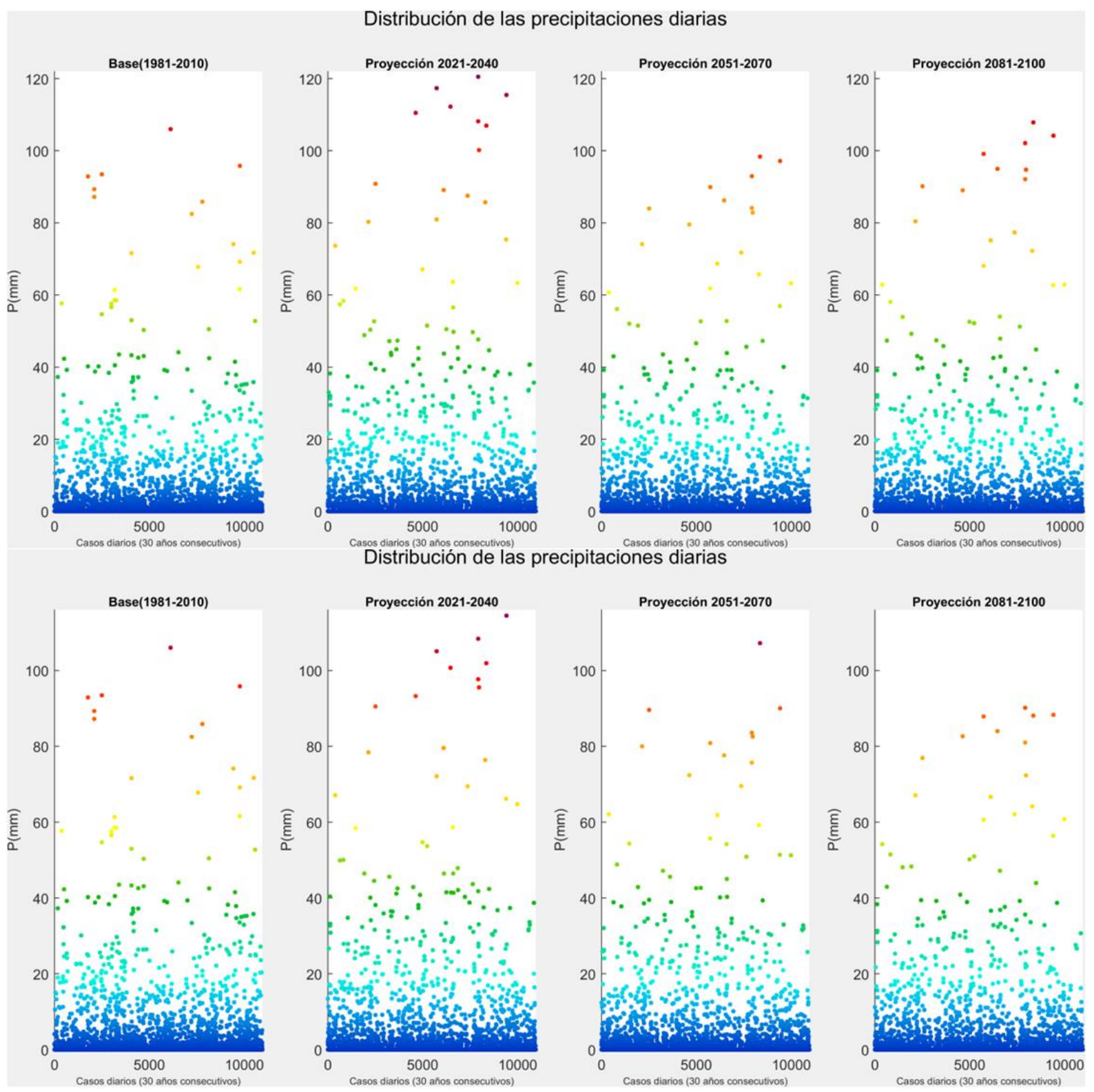

Figure 19. Benidorm local case: daily rainfall distribution obtained from LARS-WG. Ensemble HR GCMs, scenario 4.5 (upper) and 8.5 (lower).

Thus, the use of high-resolution climate models will be in demand in the near future because of the need to include projections in local spatial planning. In such planning, measures must be designed to cushion the impact of a change in temperature and pre- 
cipitation by means of urban design measures, hydraulic infrastructures and thermally isolated buildings.

\section{Conclusions}

- A trend towards greater irregularity and pluviometric torrential rain in the short term is foreseen, along with loss of precipitation in the long term. This is coherent with the analysis performed on the increased intensity of precipitations for the Mediterranean littoral overall;

- Clear spatial differences, along with greater pluviometric loss towards inland headwaters where the main rivers supplying the region rise. This loss appears in the short term and is aggravated in the long term. In some littoral areas in the Júcar and Segura River Basins, annual and seasonal precipitations increase (especially in autumn) in relation to the higher frequency of rainfall storms with sea flows, which have already been noted in recent decades;

- In seasonal terms, greater losses in precipitation are projected for spring and summer. However, reduced rainfall in the Júcar headwaters is found even in winter, which will be aggravated throughout this century, and will become a matter of concern for emission scenario RCP8.5;

- Trend towards prolonged drought periods;

- Coherent results with ongoing trends previously noted in the past for the same study area in the work of Miró et al. [38];

- The high-resolution climate modeling results allow graphical and cartographical outputs to be obtained on a detailed scale, which is very useful for land and town planning and for water resource management. This aspect will substantially develop in forthcoming years in line with complying with certain contents in State and Spanish Autonomous Community laws on climate change and with plans to adapt to climate change at a local (municipal) scale.

Author Contributions: Conceptualization, J.J.M., M.J.E. and J.O.-C.; methodology, J.J.M.; software, J.J.M.; validation, J.J.M. and M.J.E.; formal analysis, J.J.M., M.J.E., J.O.-C. and J.M.-V.; investigation, J.J.M., M.J.E. and J.O.-C.; resources, J.J.M., M.J.E., J.O.-C. and J.M.-V.; data curation, J.J.M.; writing—original draft preparation, J.J.M., M.J.E., J.O.-C. and J.M.-V.; writing-review and editing, J.J.M., M.J.E., J.O.-C. and J.M.-V.; visualization, J.J.M., M.J.E., J.O.-C. and J.M.-V. All authors have read and agreed to the published version of the manuscript.

Funding: This research was funded by the spanish CLICES project (CGL2017-83866-C3-2-R, AEI/FEDER, UE) and the Tool4Extreme project (PID2020-118797RB-100).

Institutional Review Board Statement: Not applicable.

Informed Consent Statement: Not applicable.

Data Availability Statement: Data available on request from the authors.

Conflicts of Interest: The authors declare no conflict of interest. The funders had no role in the design of the study; in the collection, analyses, or interpretation of data; in the writing of the manuscript, or in the decision to publish the results.

\section{References}

1. Swiss Re. Catástrofes Naturales en Tiempos de Acumulación Económica y Riesgos Climáticos. Informes Sigma 2/2020. Available online: https://www.swissre.com/institute/research/sigma-research/sigma-2020-02.html (accessed on 3 July 2021).

2. Giorgi, F. Climate Change Hot-Spots. Geophys. Res. Lett. 2006, 33, L08707. [CrossRef]

3. Cramer, W.; Guiot, J.; Fader, M.; Garrabou, J.; Gattuso, J.-P.; Iglesias, A.; Lange, M.A.; Lionello, P.; Llasat, M.C.; Paz, S.; et al. Climate change and interconnected risks to sustainable development in the Mediterranean. Nat. Clim. Chang. 2018, 8, 972-980. [CrossRef]

4. WHO. Deaths Related to Flooding per Million Inhabitants (Cumulative over the Period 1991-2015, with Respect to 2015 Population). Map Format. 2016. Available online: https://www.eea.europa.eu/data-and-maps/figures/people-per-millionpopulation-affected-4 (accessed on 3 July 2021). 
5. Mediterranean Experts on Climate and Environmental Change (MedECC); Union for the Mediterranean; Plan Bleu (UNEP/MAP Regional Activity Center). Risks Associated to Climate and Environmental Changes in the Mediterranean Region. A Preliminary Assessment by the MedECC Network Science-Policy Interface-2019; UNEP/MAP Regional Activity Center: Marseille, France, 2019.

6. Held, I.M.; Soden, B.J. Robust responses of the hydrological cycle to global warming. J. Clim. 2006, 19, 5686-5699. [CrossRef]

7. Frauenfeld, O.W.; Davis, R.E. Northern Hemisphere circumpolar vortex trends and climate change implications. J. Geophys. Res. Atmos. 2003, 108, 4423. [CrossRef]

8. Trenberth, K.E.; Jones, P.D.; Ambenje, P.; Bojariu, R.; Easterling, D.; Klein Tank, A.; Parker, D.; Rahimzadeh, F.; Renwick, J.A.; Rusticucci, M.; et al. Observations: Surface and Atmospheric Climate Change. 2007. Available online: https://www.ipcc.ch/site/ assets / uploads/2018/02/ar4-wg1-chapter3-1.pdf (accessed on 3 July 2021).

9. Barcikowska, M.J.; Kapnick, S.; Feser, F. Impact of large-scale circulation changes in the North Atlantic sector on the current and future Mediterranean winter hydroclimate. Clim. Dyn. 2018, 50, 2039-2059. [CrossRef]

10. Zappa, G. Regional Climate Impacts of Future Changes in the Mid-Latitude Atmospheric Circulation: A Storyline View. Curr. Clim. Chang. Rep. 2019, 5, 358-371. [CrossRef]

11. Sánchez, E.; Domínguez, M.; Romera, R.; López-Franca, N.; Gaertner, M.A.; Gallardo, C.; Castro, M. Regional modeling of dry spells over the Iberian Peninsula for present climate and climate change conditions. Clim. Chang. 2011, 107, 625-634. [CrossRef]

12. González-Hidalgo, J.C.; De Luis, M.; Raventós, J.; Sánchez, J.R. Daily rainfall trend in the Valencia region of Spain. Theor. Appl. Climatol. 2003, 75, 117-130. [CrossRef]

13. De Luis, M.; González-Hidalgo, J.C.; Brunetti, M.; Longares, L.A. Precipitation concentration changes in Spain 1946-2005. Nat. Hazards Earth Syst. Sci. 2011, 11, 1259-1265. [CrossRef]

14. De Luis, M.; González-Hidalgo, J.C.; Longares, L.A.; Štepánek, P. Seasonal Precipitation trends in the Mediterranean Iberian Peninsula in second half of 20th century. Int. J. Climatol. 2009, 29, 1312-1323. [CrossRef]

15. De Luis, M.; Brunetti, M.; Gonzalez-Hidalgo, J.C.; Longares, L.A.; Martin-Vide, J. Changes in seasonal precipitation in the Iberian Peninsula during 1946-2005. Glob. Planet. Chang. 2010, 74, 27-33. [CrossRef]

16. González-Hidalgo, J.C.; López-Bustins, J.A.; Štepánek, P.; Martín-Vide, J.; De Luis, M. Monthly precipitation trends on the Mediterranean fringe of the Iberian Peninsula during the second half of the 20th century (1951-2000). Int. J. Climatol. 2009, 29, 1415-1429. [CrossRef]

17. López-Moreno, J.I.; Vicente-Serrano, S.M.; Gimeno, L.; Nieto, R. Stability of the seasonal distribution of precipitation in the Mediterranean region: Observations since 1950 and projections for the 21st century. Geophys. Res. Lett. 2009, 36 , L10703. [CrossRef]

18. Bladé, I.; Cacho, I.; Castro-Díez, Y.; Gomis, D.; González-Sampériz, P.; Miguez-Macho, G.; Perez Fiz, F.; Rodríguez-Fonseca, B.; Rodríguez-Puebla, C.; Sánchez, E.; et al. Tendencias Atmosfericas en la Peninsula Iberica durante el Periodo Instrumental en el Contexto de la Variabilidad Natural. In Clima en España: Pasado, Presente y Futuro; Perez, F., Boscoso, R., Eds.; Red Tematica CLIVAR-ESPANA: Madrid, Spain, 2010; pp. 25-42. Available online: http://digital.csic.es /handle/10261/23600?1ocale=en (accessed on 3 July 2021).

19. Del Río, S.; Herrero, L.; Fraile, R.; Penas, A. Spatial distribution of recent rainfall trends in Spain (1961-2006). Int. J. Climatol. 2011, 31, 656-667. [CrossRef]

20. Serra, C.; Burgueño, A.; Martínez, M.D.; Lana, X. Trends in dry spells across Catalonia (NE Spain) during the second half of the 20th century. Theor. Appl. Climatol. 2006, 85, 165. [CrossRef]

21. Millán, M.M.; Estrela, M.J.; Miró, J.J. Rainfall Components: Variability and Spatial Distribution in a Mediterranean Area (Valencia Region). J. Clim. 2005, 18, 2682-2705. [CrossRef]

22. Miró, J.J.; Estrela, M.J.; Pastor, F.; Millán, M. Análisis comparativo de tendencias en la precipitación, por distintos inputs, entre los dominios hidrológicos del Segura y del Júcar (1958-2008). Investig. Geogr. 2009, 49, 129-157. [CrossRef]

23. Miró, J.J.; Estrela, M.J.; Olcina-Cantos, J. Statistical downscaling and attribution of air temperature change patterns in the Valencia region (1948-2011). Atmos. Res. 2015, 156, 189-212. [CrossRef]

24. Fovargue, R.E.; Rezapour, S.; Rosendahl, D.; Wootten, A.M.; Sabzi, H.Z.; Moreno, H.A.; Neeson, T.M. Spatial planning for water sustainability projects under climate uncertainty: Balancing human and environmental water needs. Environ. Res. Lett. 2021, 16, 034050. [CrossRef]

25. Kharel, G.; Kirilenko, A. Comparing CMIP-3 and CMIP-5 climate projections on flooding estimation of Devils Lake of North Dakota, USA. PeerJ 2018, 6, e4711. [CrossRef]

26. Navarro-Racines, C.E.; Tarapues, J.; Thornton, P.; Jarvis, A.; Ramirez-Villegas, J. High-resolution and bias-corrected CMIP5 projections for climate change impact assessments. Sci. Data 2020, 7, 7. [CrossRef]

27. Zhao, L.; Oleson, K.; Bou-Zeid, E.; Krayenhoff, E.S.; Bray, A.; Zhu, Q.; Zheng, Z.; Chen, C.; Oppenheimer, M. Global multi-model projections of local urban climates. Nat. Clim. Chang. 2021, 11, 152-157. [CrossRef]

28. Gebhardt, O.; Meyer, M. EU FP-7 Project "Bottom-up Climate Adaptation Strategies towards a Sustainable Europe-BASE" and Projektgruppe "Campus Inselplatz". 2020. Available online: https:/ / climate-adapt.eea.europa.eu/metadata/case-studies/ mainstreaming-climate-change-adaptation-into-urban-planning-greyfield-land-redevelopment-in-jena-germany/\#source (accessed on 3 July 2021).

29. Mishra, B.; Emam, A.R.; Masago, Y.; Kumar, P.; Regmi, R.K.; Fukushi, K. Assessment of future flood inundations under climate and land use change scenarios in the Ciliwung River Basin, Jakarta. J. Flood Risk Manag. 2018, 11, S1105-S1115. [CrossRef] 
30. Hassan, I.; Kalin, R.M.; White, C.J.; Aladejana, J.A. Selection of CMIP5 GCM Ensemble for the Projection of Spatio-Temporal Changes in Precipitation and Temperature over the Niger Delta, Nigeria. Water 2020, 12, 385. [CrossRef]

31. Blenkinsop, S.; Harpham, C.; Burton, A.; Goderniaux, P.; Brouyère, S.; Fowler, H.J. Downscaling transient climate change with a stochastic weather generator for the Geer catchment, Belgium. Clim. Res. 2013, 57, 95-109. [CrossRef]

32. Burton, A.; Fowler, H.; Blenkinsop, S.; Kilsby, C. Downscaling transient climate change using a Neyman-Scott Rectangular Pulses stochastic rainfall model. J. Hydrol. 2010, 381, 18-32. [CrossRef]

33. De Luca, D.L.; Petroselli, A.; Galasso, L. A Transient Stochastic Rainfall Generator for Climate Changes Analysis at Hydrological Scales in Central Italy. Atmosphere 2020, 11, 1292. [CrossRef]

34. Kilsby, C.; Jones, P.; Burton, A.; Ford, A.; Fowler, H.; Harpham, C.; James, P.; Smith, A.; Wilby, R. A daily weather generator for use in climate change studies. Environ. Model. Softw. 2007, 22, 1705-1719. [CrossRef]

35. Onof, C.; Arnbjerg-Nielsen, K. Quantification of anticipated future changes in high resolution design rainfall for urban areas. Atmos. Res. 2009, 92, 350-363. [CrossRef]

36. Rodríguez, E.; Gutiérrez, J.R. (coords). Escenarios-PNACC 2017: Nueva Colección de Escenarios de Cambio Climático Regionalizados del Plan Nacional de Adaptacioń al Cambio Climático (PNACC). V 1.0, AEMET. 2018. Available online: http:/ / escenarios.adaptecca.es/doc/pnacc.pdf (accessed on 3 July 2021).

37. Miró, J.J.; Caselles, V.; Estrela, M.J. Multiple imputation of rainfall missing data in the Iberian Mediterranean context. Atmos. Res. 2017, 197, 313-330. [CrossRef]

38. Miró, J.J.; Estrela, M.J.; Caselles, V.; Gómez, I. Spatial and temporal rainfall changes in the Júcar and Segura basins (1955-2016): Fine-scale trends. Int. J. Climatol. 2018, 38, 4699-4722. [CrossRef]

39. Benestad, R. Downscaling Climate Information. Oxford Research Encyclopedia of Climate Science. 2016. Available online: https:/ / oxfordre.com/climatescience/view /10.1093/acrefore/9780190228620.001.0001/acrefore-9780190228620-e-27 (accessed on 29 June 2021). [CrossRef]

40. Fan, X.; Miao, C.; Duan, Q.; Shen, C.; Wu, Y. The Performance of CMIP6 versus CMIP5 in Simulating Temperature Extremes over the Global Land Surface. J. Geophys. Res. Atmos. 2020, 125. [CrossRef]

41. Khan, M.S.; Coulibaly, P.; Dibike, Y. Uncertainty analysis of statistical downscaling methods. J. Hydrol. 2006, 319, 357-382. [CrossRef]

42. Samadi, S.; Wilson, C.; Moradkhani, H. Uncertainty analysis of statistical downscaling models using Hadley Centre Coupled Model. Theor. Appl. Clim. 2013, 114, 673-690. [CrossRef]

43. Semenov, M.; Barrow, E. LARS-WG A Stochastic Weather Generator for Use in Climate Impact Studies. Clim. Chang. 2002, 35, 397-414. [CrossRef]

44. Wilby, R.; Dawson, C.; Barrow, E. SDSM-A decision support tool for the assessment of regional climate change impacts. Environ. Model. Softw. 2002, 17, 145-157. [CrossRef]

45. Hashmi, M.Z.; Shamseldin, A.Y.; Melville, B.W. Comparison of SDSM and LARS-WG for simulation and downscaling of extreme precipitation events in a watershed. Stoch. Environ. Res. Risk Assess. 2010, 25, 475-484. [CrossRef]

46. Duan, K.; Mei, Y. A comparison study of three statistical downscaling methods and their model-averaging ensemble for precipitation downscaling in China. Theor. Appl. Clim. 2014, 116, 707-719. [CrossRef]

47. Moghanlo, S.; Alavinejad, M.; Oskoei, V.; Saleh, H.N.; Mohammadi, A.A.; Mohammadi, H.; Derakhshan-Nejad, Z. Using artificial neural networks to model the impacts of climate change on dust phenomenon in the Zanjan region, north-west Iran. Urban Clim. 2021, 35, 100750. [CrossRef]

48. Conte, D.; Gualdi, S.; Lionello, P. Effect of Model Resolution on Intense and Extreme Precipitation in the Mediterranean Region. Atmosphere 2020, 11, 699. [CrossRef]

49. Brands, S.; Herrera, S.; Fernández, J.; Gutiérrez, J.M. How well do CMIP5 Earth System Models simulate present climate conditions in Europe and Africa? A performance comparison for the downscaling community. Clim. Dyn. 2013, 41, 803-817. [CrossRef]

50. Perez, J.; Menendez, M.; Mendez, F.; Losada, I.J. Evaluating the performance of CMIP3 and CMIP5 global climate models over the north-east Atlantic region. Clim. Dyn. 2014, 43, 2663-2680. [CrossRef]

51. McSweeney, C.F.; Jones, R.; Lee, R.; Rowell, D.P. Selecting CMIP5 GCMs for downscaling over multiple regions. Clim. Dyn. 2015, 44, 3237-3260. [CrossRef]

52. Noël, T.; Loukos, H.; Defrance, D.; Vrac, M.; Levavasseur, G. A high-resolution downscaled CMIP5 projections dataset of essential surface climate variables over the globe coherent with the ERA5 reanalysis for climate change impact assessments. Data Brief. 2021, 35, 106900. [CrossRef]

53. Hempel, S.; Frieler, K.; Warszawski, L.; Schewe, J.; Piontek, F. A trend-preserving bias correction: The ISI-MIP approach. Earth Syst. Dyn. 2013, 4, 219-236. [CrossRef]

54. Reale, M.; Lionello, P. Synoptic climatology of winter intense precipitation events along the Mediterranean coasts. Nat. Hazards Earth Syst. Sci. 2013, 13, 1707-1722. [CrossRef]

55. Pastor, F.; Valiente, J.; Khodayar, S. A Warming Mediterranean: 38 Years of Increasing Sea Surface Temperature. Remote Sens. 2020, 12, 2687. [CrossRef]

56. Greco, A.; De Luca, D.L.; Avolio, E. Heavy Precipitation Systems in Calabria Region (Southern Italy): High-Resolution Observed Rainfall and Large-Scale Atmospheric Pattern Analysis. Water 2020, 12, 1468. [CrossRef] 
57. Miró, J.J.; Estrela, M.J.; Olcina-Cantos, J. Reconstrucción de la señal térmica local en la Comunidad Valenciana entre 1948 y 2011 a partir de un downscaling estadístico mediante una red neuronal artificial: Detección de patrones locales de cambio. Bol. Asoc. Geogr. Esp. 2016, 70, 113-147. [CrossRef]

58. Miró, J.J.; Estrela, M.J.; Caselles, V.; Olcina-Cantos, J. Fine-scale estimations of bioclimatic change in the Valencia region, Spain. Atmos. Res. 2016, 180, 150-164. [CrossRef]

59. Oria Iriarte, P. ¿Está Aumentando la Intensidad de las Precipitaciones Extremas en el Mediterráneo? Calendario Meteorológico. 2021. Available online: https:/ / aemetblog.es/2021/05/02/esta-aumentando-la-frecuencia-o-la-intensidad-de-las-precipitacionesextremas-en-el-mediterraneo/ (accessed on 3 July 2021).

60. CEDEX. Evaluación del Impacto del Cambio Climático en los Recursos Hídricos y Sequías en España; Centro de Estudios Hidrográficos: Madrid, Spain, 2017; 320p. Available online: http:/ / www.cedex.es/NR/rdonlyres/3B08CCC1-C252-4AC0-BAF7-1BC2726653 4B/145732/2017_07_424150001_Evaluación_cambio_climático_recu.pdf (accessed on 3 July 2021).

61. Rubio-Martin, A.; Pulido-Velazquez, M.; Macian-Sorribes, H.; Garcia-Prats, A. System Dynamics Modeling for Supporting Drought-Oriented Management of the Jucar River System, Spain. Water 2020, 12, 1407. [CrossRef] 